\title{
Rovinná sídliště starší a počátku střední doby bronzové na Českobudějovicku
}

\author{
Flat settlements of the Early and Early Middle Bronze Ages \\ in the České Budějovice region
}

\section{Ondřej Chvojka}

\begin{abstract}
Abstrakt
Článek přináší analýzu rovinných sídlišt' starší až počátku střední doby bronzové (Br A2 - B1) na Českobudějovicku, tj. v jedné z uzlových oblastí jihočeského regionu sledované epochy. Celkem je zde dnes známých 16 sídlišt', žádné z nich však dosud nebylo odkryto kompletně. Všechna sídliště jsou vázána na tok řeky Vltavy či jejích přítoků. Některá se nacházejí v nivních oblastech, další na svazích, terasách či návrších. Za pozornost stojí výrazná vazba analyzovaných sídlišt' na písčité podloží. S výjimkou sídliště v Hostech zatím analyzované lokality nepřinesly bezpečné doklady obytných staveb. Uvedené sídliště v Hostech poskytlo doklady specializované výroby (metalurgie mědi/bronzu) i dálkového obchodu. Ten dokládají i nálezy jantaru z Hostů, Borku a snad i z Plava. Sídliště tvořila součást tehdejší sídelní struktury, žádné nebylo zcela izolované.
\end{abstract}

\section{Klíčová slova}

rovinná sídliště - starší doba bronzová - jižní Čechy - topografie - sídelní struktura

\begin{abstract}
The article presents an analysis of flat settlements of the Early and the beginning of the Middle Bronze Age ( $\mathrm{Br} \mathrm{A} 2$ - B1) in the České Budějovice region, i.e. in one of the nodal areas of the South Bohemian region of the observed epoch. A total of 16 settlements are known here today, but none of them has been completely discovered yet. All sites are connected to the flow of the Vltava River or its tributaries. Some are located in floodplain areas, others on slopes, terraces or hills. It is worth noting the strong connection of the analyzed settlements to the sandy subsoil. With the exception of the settlement in Hosty, the analyzed sites have not yet provided secure documents for residential buildings. The mentioned settlement in Hosty provided documents of specialized production (copper/bronze metallurgy) and long-distance trade. This is also evidenced by the findings of amber from Hosty, Borek and perhaps even from Plav. The settlements were part of the then settlement structure, none was completely isolated.
\end{abstract}

\section{Key words}

flatland settlements - Early Bronze Age - South Bohemia - topography - settlement structure 


\section{Úvod}

Hlavní prameny poznání starší a počátku střední doby bronzové představovaly v jižních Čechách dlouhou dobu výšinné lokality, mohylová pohřebiště a depoty (srov. např. Hájek 1954; Havlice 2001; Moucha 2005; Chvojka 2007; Hlásek a kol. 2015). Teprve v posledních desetiletích roste v tomto regionu počet známých a odborně prozkoumaných rovinných sídlišt (Hlásek Chvojka 2019, Fig. 2). Řada z nich byla v posledních 30 letech zkoumána na Českobudějovicku, tj. v jednom z uzlových mikroregionů jižních Čech, kde se v tomto období výrazně koncentrovalo osídlení (Hlásek - Chvojka 2019, Fig. 4-5). Co mají tato sídlišstě společného a v čem se odlišují? Jsou něčím specifická z topografického hlediska? Existují na nich doklady specializované výroby či napojení na dálkový obchod? Lze vysledovat jejich vztah k soudobým hradištím, pohřebištím či dalším areálům lidských aktivit? Je Českobudějovicko z hlediska sídelních strategií odlišné od okolních oblastí? Na tyto i další otázky jsou hledány odpovědi v předloženém příspěvku, v němž jsou rovněž shrnuty nejnovější poznatky z výzkumů, které většinou dosud ještě nebyly podrobněji publikovány.

\section{Vymezení sledovaného tématu}

„Rovinné (též nížinné) sídliště“, je jeden z pojmů, spadajících v rámci tzv. prostorové archeologie do kategorie areálů aktivit (srov. Kuna a kol. 2004, 465-466; Neustupný 2010, 143). Jedná se přitom o označení místa, kde lidé sídlili a vykonávali další běžné činnosti, jako podomáckou i specializovanou výrobu, výměnu zboží, uskladnění a zpracování produktů apod. (Neustupný 2010, 144-145). Na okrajích sídlišst či $\mathrm{v}$ určitých vymezených areálech v intravilánech osad mohla být chována domácí zviŕata, mohly se zde nacházet i záhony apod.
Zdaleka ne všechna sídliště v námi sledované oblasti přinesla jednoznačné doklady obytných staveb, pro zařazení lokality do kategorie „rovinné sídliště“ byla nicméně určující i přítomnost jiných sídlištních objektů (jam různých funkcí a podob, kůlových/sloupových jamek) a sídlištní vrstvy; vyloučena tak byla jen povrchově detekovaná naleziště. Dostáváme se tím sice do rizika, že do kategorie „sídliště“ byly zařazeny i lokality, kde se de facto nesídlilo, ale vzhledem k velmi malému počtu bezpečně prokázaných či alespoň předpokládaných obytných staveb (což je ovšem obecný problém sídlišt doby bronzové na našem území: srov. Parma 2015, 98) by vynechání lokalit bez doložených obytných objektů znemožnilo provedení následných analýz. Žádné sídliště ve sledované oblasti nebylo zatím odkryto celé a většina lokalit byla rovněž postižena sekundárním narušením (erozí, hlubokou orbou, novodobou zástavbou aj.), takže u dále pojednávaných sídlišt nelze vyloučit, resp. lze předpokládat původní přítomnost obytných staveb.

Z chronologického hlediska budou sledována sídliště z intervalu $\mathrm{Br} \mathrm{A} 2$ až $\mathrm{Br} \mathrm{B} 1$, který v jižních Čechách představuje nejstarší úsek osídlení doby bronzové (srov. Hlásek - Chvojka 2019). Tradičně je v analyzovaném regionu tato epocha označována jako „starší doba bronzová“, ačkoliv její nejmladší fáze (Br B1) již spadá do střední doby bronzové. Jižní Čechy zažívají v této době dynamický kontinuální vývoj, který je přerušen až kolem roku 1500 př. Kr. nástupem mohylové kultury. Velká většina dále pojednávaných rovinných sídlišt ovšem neumožňuje přesnější dataci než obecně do „starší doby bronzové", ačkoliv stále přibývající radiokarbonová data naznačují rozptyl jednotlivých lokalit ve všech fázích sledované epochy.

Pojednávané území představuje širší koridor řeky Vltavy včetně jejích přítoků, ležící v prostoru dnešního okresu České Budějovice (obr. 1). V severo-jižním směru má délku cca $40 \mathrm{~km}$, ve směru západo-východním cca $20 \mathrm{~km}$. Na jihu je 


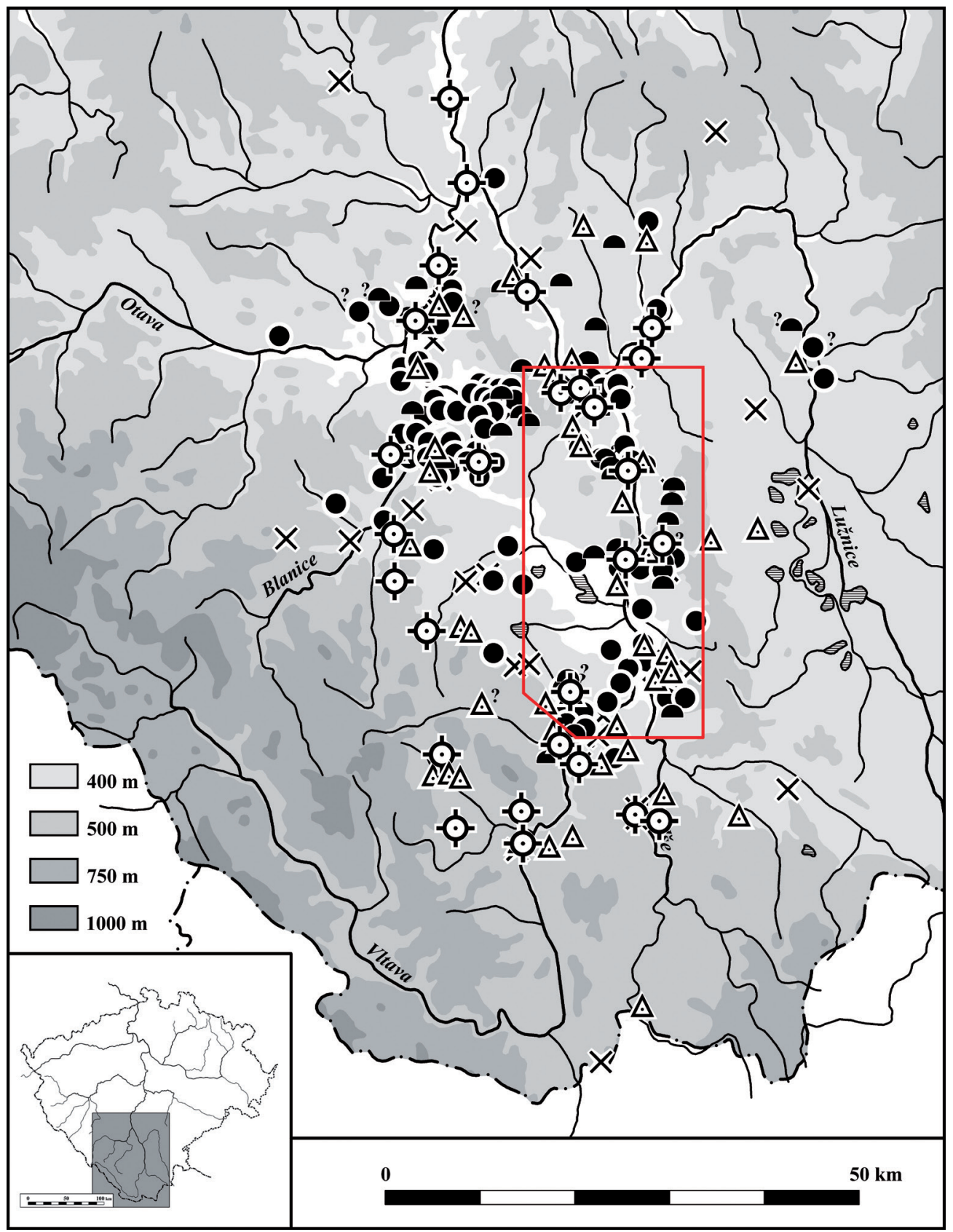

Obr. 1. Osídlení jižních Čech ve starší a na počátku střední doby bronzové s vyznačením analyzované oblasti Českobudějovicka (červený rámeček). Podle Chvojka 2007, obr. 1; upraveno.

Abb. 1. Besiedlung Südböhmens in der Frühbronzezeit und am Anfang der Mittelbronzezeit mit Bezeichnung des analysierten Gebietes um České Budějovice (rote Umrahmung). In Anlehnung an Chvojka 2007, obr. 1. 
ohraničeno SV výběžky Blanského lesa a jižním okrajem Českobudějovické pánve, v severní polovině pak spadá do Táborské pahorkatiny, jejíž součástí je tzv. Lišovský práh, vymezující sledované území na východě. Jižně od něj se nachází Českokrumlovsko s bohatými doklady lidských aktivit v této epoše, avšak zatím bez jednoznačných rovinných sídlišt (Chvojka a kol. 2018a, 25-33). Východně od analyzovaného území leží Třeboňská pánev, v níž zatím doklady osídlení starší a počátku střední doby bronzové absentují. Západně je situován mikroregion západní části Českobudějovické pánve a dolního toku Blanice, severně pak osídlení plynule přechází do oblasti Písecka a Bechyňska (Hlásek - Chvojka 2019, Pl. 3/1).

\section{Soupis a základní charakteristika lokalit}

Ve sledovaném území je dnes známých celkem 16 rovinných sídlišt datovatelných do průběhu starší až počátku střední doby bronzové (obr. 2). Mimo ně je zde známých několik desítek dalších potenciálních sídlišt', která však zatím dle aktuálního stavu poznání takto s jistotou klasifikovat nelze. Základní charakteristiku analyzovaných lokalit přináší následující soupis, kde jsou jednotlivá sídliště řazena abecedně. U každého je uvedena jeho lokalizace $(L o k)$ včetně koordinátů v systému WGS-84 odečtených z portálu www.mapy.cz (uveden je vždy přibližný střed lokality). Následuje stručný popis nálezových okolností (Okol) a základní literatura (Lit) $\mathrm{k}$ dané lokalitě. Všechny lokality leží na území okresu České Budějovice.

1. Borek. Lok: Bezejmenné návrší v lese Borek, obtékaného z východní a jižní strany potokem Kyselá voda. 49.0252533N, 14.5092678E. Okol: Lokalita byla objevena v červnu 2015 při archeologickém výzkumu Jihočeského muzea v trase nově budované dálnice D3. Zjištěny a následně prozkoumány zde byly celkem 3 zahloubené objekty, z nichž dva představují menší jamky a jeden pak rozsáhlou prohlubeň zaplněnou sídlištním odpadem. Posledně zmíněný objekt poskytl jeden z největších souborů sídlištních nálezů starší doby bronzové v jižních Čechách, čítající více než 6500 keramických zlomků i slepených nádob (celková hmotnost keramiky převyšovala $100 \mathrm{~kg}$ ), soubor několika kamenných otloukačů, zlomků podložek, kamenné štípané industrie i hrudek grafitu. Díky pečlivému plavení odebraných vzorků se podařilo identifikovat větší množství drobných kousků jantaru, které tak dokládají oblibu tohoto vzácného materiálu i mezi obyvateli běžných rovinných osad. Ze získaného rostlinného semena se podařilo získat radiokarbonové datum 1776-1630 př. Kr. Sídliště bylo zkoumáno pouze ve skryté trase pro budoucí dálnici (v délce cca $300 \mathrm{~m}$ ), evidentně ale pokračovalo i mimo prostor stavby. Lit.: Chvojka - Zavřel 2019, 8; Chvojka - Šálková - Š́da a kol. 2021.

2. České Budějovice. Lok: Zahrada p. Čalouna ppč. 1737 v zahrádkářské kolonii mezi silnicí do Českého Krumlova a řekou Vltavou. 48.9638936N, 14.4626242E. Okol: Při stavbě bazénu a jímky zachytil P. Zavřel v letech 19921994 a 1997 početnou keramiku v ř́čćních náplavech. Nálezy byly učiněny v hloubce 1,4-1,5 m pod současným povrchem. Starobronzové sídliště posloužilo i ke studiu říčních akumulačních procesů. Lit: Zavřel 1993, 9-11, obr. 9; Beneš 1995, 134, 140.

3. České Budějovice. Lok: Prostor obchodní zóny u Dobrovodské stoky severně od Strakonické silnice (stavba obchodních domů Terno, Baumax). 48.9940903N, 14.4706036E. Okol: Lokalitu objevil v roce 1992 P. Zavřel při povrchovém sběru, kdy zde nalezl keramické zlomky datovatelné jen obecně do pravěku. Přesnější 


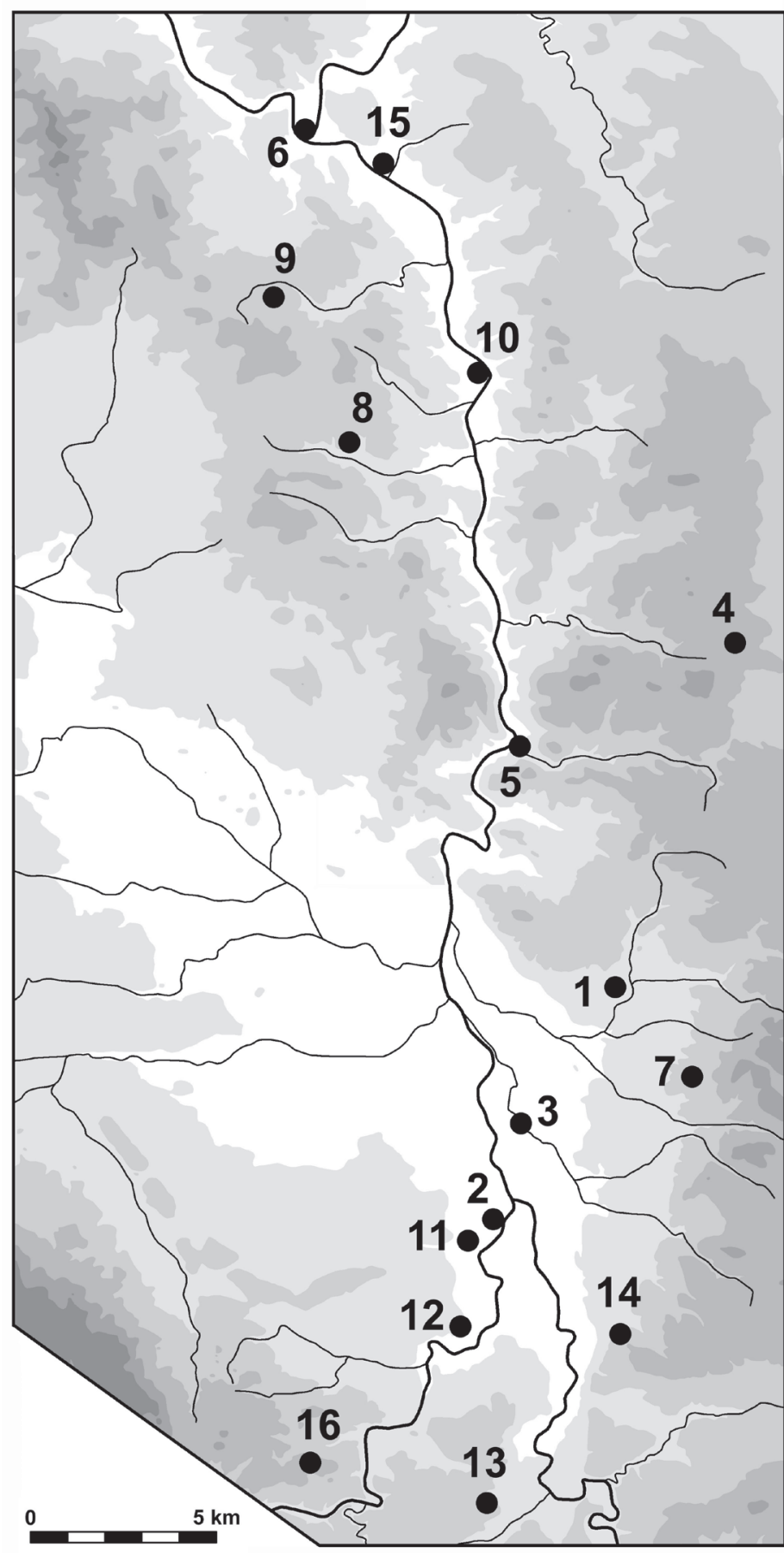

Obr. 2. Rovinná sídliště starší a počátku střední doby bronzové na Českobudějovicku. Mapový podklad: K. Vávra.

Abb. 2. Flachlandsiedlungen der Frühbronzezeit und des Anfangs der Mittelbronzezeit in der Region um České Budějovice. Kartengrund: K. Vávra. 
chronologické zařazení přinesly až sondážní výzkumy: sítí sond se v letech 1995 a 1999 podařilo P. Zavřelovi zachytit rozplavenou sídlištní vrstvu s nálezy keramiky a dřev. Mezi nálezy patří i torzo nádoby obsahující zbytky trav a zvírecí zuby. Významné poznatky pak přinesla pylová analýza z odebraných sedimentů. Radiokarbonová data z nalezených dřev potvrdila da-

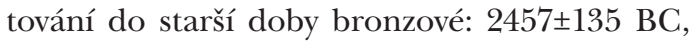
$1714 \pm 136$ BC a 1634 \pm 135 BC. Lit: Zavřel 1993, 7, lok. č. 33; Jankouská 2001; Pokorný a kol. 2002.

4. Dobřejovice. Lok: Pískovna v lese Osiková, ppč. 2745 , v těsném severním sousedství raně středověkého mohylového pohřebiště. 49.1060439N, 14.5456428E. Okol: Lokalitu objevil A. Beneš při povrchovém sběru v roce 1973. V roce 1976 zachytil tentýž autor při záchranné akci v pískovně sídlištní objekt obdélné dispozice $(110 \times 225 \mathrm{~cm})$ hluboký max. $1 \mathrm{~m}$ ze starší doby bronzové, který obsahoval zlomky keramiky, uhlíky a hrudku grafitu. Lit: Beně̌ 1981, 28.

5. Dobřejovice. Lok: Ostrožna u sv. Jana mezi potoky a Vltavou, v trase silnice Hluboká nad Vltavou - Poněšice. 49.0848953N, 14.4703247E. Okol: Při úpravě komunikace v roce 1989 zjistil P. Břicháček na temeni ostrožny kulturní vrstvu s nálezy keramiky ze starší doby bronzové. Lit: Břicháček 1992, 28.

6. Hosty. Lok: Trat „Pod Novým dvorem“ na soutoku Vltavy a Lužnice, č. kat. 882. V současné době je lokalita vybagrována a zatopena. 49.2316914N, 14.3900086E. Okol: Lokalitu objevil J. Fröhlich při povrchovém sběru v roce 1968. V letech 1981-1988 zde proběhl záchranný výzkum vedený $\mathrm{A}$. Benešem, při kterém byl zjištěn osídlený areál na ploše asi 3 ha. V délce 60 m byla prozkoumána kulturní vrstva o mocnosti 35-40 cm, díky níž byly zjištěny dvě (případně tři) fáze osídlení. Mezi sídlištními objekty bylo identifikováno větší množství kủlových chat o rozměrech od 4,3 $\times 4,8 \mathrm{~m}$ do $11,5 \times 7,5 \mathrm{~m}$, v jejichž okolí se nacházely zásobní jámy. Stavba tvořená dvěma řadami kamenů byla především na základě nálezů hliněných idolů interpretována jako kultovní objekt. Osada byla opevněna dvěma nesoučasnými příkopy o šířce 2 a 4 m a hloubce $2 \mathrm{~m}$. Lokalita poskytla mimořádně velké množství výjimečných artefaktů, z nichž část není lokálního původu - identifikovány zde byly prvky karpatských kultur i výrobky z dalších evropských oblastí. Metalurgie byla v Hostech doložena slévačským tyglíkem, dyznami, odlévací formou na sekery a slitky bronzoviny. Lit: Beneš 1984; 1988; 1989; Břicháček 1991; Ernée 2008, 38-41.

7. Hůry. Lok: Louka v trati Nad výhony, cca $350 \mathrm{~m}$ západně od obce. 49.0049889N, 14.5307297E. Okol: Ve skrývce pro novou kanalizaci objevil a následně prozkoumal $\mathrm{P}$. Zavřel v roce 2001 celkem 8 objektů ze starší doby bronzové - obdélnou „chatu“ o rozměrech $8 \times 3 \mathrm{~m}$, mírně $(20 \mathrm{~cm})$ zahloubenou do podloží, kterou lemovalo 7 jam. Lit: Zavřel 2003, 82.

8. Knín (Býšov). Lok: Pole přiléhající na západě k areálu středověké tvrze Býšov, mezi rybníkem Barbora a silnicí do Knína. 49.1602842N, 14.3980553E. Okol: V místě skrývky pro novostavbu závodu na zpracování biomasy provedl v roce 2005 O. Chvojka záchranný výzkum dosud neznámého sídliště ze starší doby bronzové. V celkem 33 sondách o celkové ploše 217,5 $\mathrm{m}^{2}$ byla zjištěna až $30 \mathrm{~cm}$ mocná sídlištní vrstva a pod ní 10 zahloubených objektů a několik kůlových jamek. Lit: Chvojka - Zavřel 2011.

9. Křtěnov. Lok: Les „Hroby“ a vedlejší louka „K hrobům“. 49.1934056N, 14.3777364E. Okol: Při záchranném archeologickém výzkumu známého mohylového pohřebiště v letech 19841985 zjistil P. Braun, že mohyly ze starší doby bronzové byly budovány př́mo na sídlišti - je- 
jich násypy obsahovaly značné množství zlomků sídlištní keramiky, hrobová komora mohyly č. 45 byla zahloubena prímo do kulturní vrstvy. Zbytky sídliště byly sondážně zjištěny rovněž na sousední louce. Lit: Braun 1987, 251.

10. Litoradlice. Lok: Okraj terasového stupně na levém břehu Vltavy, J od přehrady Hněvkovice. 49.1736297N, 14.4550486E. Okol: Při sběrech P. Břicháčka $\mathrm{v}$ roce 1989 byla $\mathrm{v}$ místech, kde byl terén uměle snížen o $30-50 \mathrm{~cm}$, nalezena keramika ze starší doby bronzové, na písčitém podloží pak byly zjištěny stopy kulturní vrstvy. Další nálezy byly zaznamenány v roce 1990 při sběrech P. Brauna. Pozn.: P. Braun uvádí dvě samostatné lokality, vzhledem k jejich velké blízkosti se však nepochybně jedná o jeden sídelní areál. Lit: Břicháček 1992, 87; Braun 1995, 187 (lok. č. 955 a 956).

11. Litvínovice. Lok: Východní okraj obce, vedle silnice České Budějovice - Český Krumlov, asi $170 \mathrm{~m} \mathrm{JZ}$ od křižovatky na Litvínovice, naproti rybníčku. 48.9620489N, 14.4558853E. Okol: Při stavbě obchodního střediska v roce 1996 zachytil P. Zavřel náplavovou vrstvu se zbytky dřev a keramikou ze starší doby bronzové. Lit: Zavřel 1998, 106.

12. Planá u Českých Budějovic. Lok: Návrší na jižním okraji obce, cca $350 \mathrm{~m} \mathrm{JZ}$ od kaple v obci, v místě skrývky pro komerční budovu. $48.9413569 \mathrm{~N}, 14.4502606 \mathrm{E}$. Okol: V roce 2008 prozkoumali O. Chvojka a $\mathrm{P}$. Zavřel tři sídlištní objekty. Do starší doby bronzové náleží větší jáma (objekt 1/08) obdélného tvaru se zaoblenými nárožími (rozm. 3,4 × 2,3 m, hloubka max. $40 \mathrm{~cm}$ ) a se dvěma kůlovými jamkami při J a SV okraji objektu. Ze starší doby bronzové je i torzo solitérního keramického hrnce (objekt 2/08), jehož dno bylo mírně zapuštěno do podloží. Třetí objekt patří střední době bronzové. Lit: Chvojka - Zavřel 2009, 24-25.
13. Plav. Lok: Prostor západního okraje známého mohylového pohřebiště v Obecním lese, v okolí mohyl č. 3-5 (srov. Beneš - Michálek - Zavřel 1999, 66, tab. 75). 48.8991678N, 14.4707833E. Okol: V souvislosti s archeologickým výzkumem tří mohyl v Plavu, zkoumaných Jihočeským muzeem v trase budoucí dálnice D3, bylo v roce 2017 zjištěno do té doby neznámé sídliště ze starší doby bronzové a z doby laténské, jehož záchranný archeologický výzkum se odehrál v roce 2018. Sídliště starší doby bronzové se projevovalo několika zahloubenými objekty a zejména písčitou kulturní vrstvou s velkým množstvím keramických zlomků i kamenné štípané industrie. Laténské sídliště pak tvořilo několik zahloubených objektů - jam a kůlových jamek. V trase skrývky pro dálnici nebyla lokalita zachycena v úplnosti - její pokračování je možné předpokládat v zalesněném prostoru západně od místa výzkumu. Patrně nezáměrně se sídlištní artefakty sekundárně dostaly i do násypů blízkých mohyl a do výplní hrobových jam, zkoumaných v těchto mohylách. Lit: Chvojka - Zavřel 2019, 8; v tisku.

14. Staré Hodějovice. Lok: Několik samostatně zkoumaných poloh tvořících nepochybně jeden sídelní areál: mezi polem $\mathrm{V}$ od silnice České Budějovice - Nedabyle, J od Nových Hodějovic po pole při silnici do Vidova. Lokalita zasahuje i do k. ú. Nových Hodějovic. $48.9454167 \mathrm{~N}, 14.5054286 \mathrm{E}$ (východní část lokality), 48.9436972N, 14.5029450E (západní část lokality). Okol: Při záchranném výzkumu ve východní části lokality v roce 1992 zachytili J. Militký a P. Zavřel kulturní vrstvu a čtyři sídlištní objekty z přelomu starší a střední doby bronzové. Kromě běžných sídlištních jam se v jednom př́ípadě jednalo o oválnou jámu s plochým dnem a skupinami kamenů na kratších stranách, kterou autoři výzkumu interpretovali jako chatu. V souvislosti se stavbou dálnice D3 prozkoumalo Jihočeské muzeum v letech 2018 
a 2019 v západní části lokality několik dalších zahloubených objektů a zbytek kulturní vrstvy s nálezy z několika pravěkých období, mj. i ze starší doby bronzové. Lit: Militký - Zavřel 1995, 56 /jako České Budějovice/; výzkum z let 2018-2019 zatím nepublikován.

15. Týn nad Vltavou. Lok: Podél západního líce fary v centru města. 49.2223067N, 14.4213428E. Okol: V roce 1987 zachytil a zdokumentoval ve výkopu kolektoru P. Břicháček kulturní vrstvu s nálezy ze starší doby bronzové. Lit: Břicháček 1989, 206.

16. Vrábče. Lok: Pískovna na Z okraji lesa Vrubice. $48.9122856 \mathrm{~N}, 14.3872853 \mathrm{E}$. Okol: Lokalitu objevil a částečně prozkoumal A. Beneš v roce 1966. Na přilehlém poli nalezl v roce 1972 keramické zlomky z přelomu starší a střední doby bronzové K. Žebera. Od roku 1982 nacházel v pískovně další nálezy ze starší doby bronzové (keramika, štípaná industrie, kamenný brousek) T. Hamberger z Českých Budějovic. Při záchranném výzkumu v roce 1997 prozkoumal P. Zavřel na lokalitě 12 sídlištních objektů ze starší doby bronzové. Lit: Zavřel 2000, 225.

\section{Topografická charakteristika analyzovaných sídlišt'}

Všech 16 dnes známých jistých sídlišt ze starší až počátku střední doby bronzové ve sledované oblasti je vázaných bud'to na tok řeky Vltavy, nebo na její přítoky (obr. 2). Některá sídliště se nacházejí přímo při dnešním břehu řeky (Č. Budějovice /č. 2/, Hosty, Litoradlice, Týn nad Vltavou), řada dalších v její blízkosti. Nejvzdálenější od Vltavy jsou sídliště v Křtěnově (vzdušnou čarou 4,5 km), Hůrách $(5,2 \mathrm{~km})$ a Dobřjovicích $(5,7 \mathrm{~km})$. Při řece Vltavě je (nejen) pro sledovanou epochu předpokládána hlavní dálková komunikace (Chvojka 2015a, 115-116, obr. 1), je ovšem otázkou, jestli a do jaké míry se lidé z těchto sídlišst na dálkovém obchodě případně podíleli. Nejvíce dokladů dálkových kontaktů poskytlo zatím jen sídliště v Hostech s mimořádným množstvím importů (srov. Beněs 1989). Mezi importy lze ovšem počítat i kousky jantaru, které byly mimo zmíněnou lokalitu u Hostů nalezeny i v Borku a patrně i v Plavu (na této lokalitě však není jasná datace jantarových nálezů, tj. jejich vazba na starobronzové sídliště anebo na mladší komponenty).

Zajímavé výsledky nabízí srovnání poloh uvedených sídlišt (tab. 1). Jejich největší počet $(5$, tj. $31 \%)$ se nachází v dnešních inundacích (nivách), čímž tyto lokality relativizují dříve převažující názor o nevhodnosti říčních niv k osídlení (srov. např. Kuna - Slabina 1987, 264). Na druhou stranu musíme v pravěku předpokládat možnou existenci mírných terasových zvýšenin či elevací v místech, kde dnes máme doložená záplavová území - současná podoba údolních niv je tak nejspíše značně odlišná od situace v době bronzové. Pro srovnání lze uvést např. situaci v jižním Německu, kde si lokalizaci některých sídlišt doby bronzové do nivních oblastí povšiml již W. Torbrügge (Torbrügge 1959, 25, 56). Pro oblast mnichovské roviny v Horním Bavorsku uvádí M. Schefzik převahu sídlišṫ na nízkých terasách a pak na okrajích či přímo uvnitř nivních oblastí. Osídlení niv je však v této době obecný fenomén od východní Francie až po Dolní Rakousko (Schefzik 2001, 190; 2006, 144).

Další analyzovaná sídliště na Českobudějovicku se nacházela na návrších (4 lokality), terasách a svazích (po 3 lokalitách), jediné pak na ostrožně. Vzhledem k statisticky nízkému počtu lokalit však z uvedených výsledků nelze činit významnější závěry. Srovnáme-li uvedené výsledky s polohami dalších jihočeských starobronzových sídlišt (Chvojka 2011, graf 1), pak vidíme větší zastoupení nivních poloh na Českobudějovicku (31\% oproti $23 \%$ v celém regi- 


\begin{tabular}{|c|l|c|c|c|l|}
\hline Číslo & Lokalita & $\begin{array}{c}\text { Rok výzkumu / } \\
\text { nálezu }\end{array}$ & Poloha & NV & \multicolumn{1}{|c|}{ Podloží } \\
\hline 1 & Borek & 2015 & terasa & 435 & písek \\
\hline 2 & Č. Budějovice & 1992 & niva & 386 & písek, říční náplavy \\
\hline 3 & Č. Budějovice & 1995,1999 & niva & 381 & písek, ř́ční náplavy \\
\hline 4 & Dobřejovice & 1976 & svah & 535 & písek \\
\hline 5 & Dobřejovice & 1989 & ostrožna & 385 & ortorula \\
\hline 6 & Hosty & $1981-1988$ & niva & 355 & písek \\
\hline 7 & Hůry & 2001 & návrší & 460 & migmatit \\
\hline 8 & Knín - Býšov & 2005 & svah & 458 & pararula \\
\hline 9 & Křtěnov & 1984 & návrší & 480 & pararula \\
\hline 10 & Litoradlice & 1989 & niva & 365 & písek, říční náplavy \\
\hline 11 & Litvínovice & 1996 & niva & 388 & písek, ř́ční náplavy \\
\hline 12 & Planá u ČB & 2008 & terasa & 400 & písek \\
\hline 13 & Plav & 2018 & návrší & 435 & písek \\
\hline 14 & St. Hodějovice & $1992,2018-2019$ & návrší & 420 & písek \\
\hline 15 & Týn n. Vlt. & 1987 & terasa & 360 & pararula \\
\hline 16 & Vrábče & 1997 & svah & 500 & písek \\
\hline
\end{tabular}

Tab. 1. Rovinná sídliště starší a počátku střední doby bronzové na Českobudějovicku. Základní charakteristika.

Tab. 1. Flachlandsiedlungen der Frühbronzezeit und des Anfangs der Mittelbronzezeit in der Region um České Budějovice. Grundlegende Charakteristik.

onu) a naopak menší zastoupení svahů (19 \% oproti $38 \%$ v celém regionu).

Z hlediska nadmořských výšek je u sledovaných lokalit poměrně značné rozmezí od 355 (Hosty) do 535 m n. m. (Dobřejovice /č. 4/); průměrná hodnota činí $421 \mathrm{~m} \mathrm{n}$. m. Prakticky stejné hodnoty dostaneme i v regionálním pohledu na všechna jihočeská sídliště této epochy (Chvojka 2011, 47).

Zvláštní pozornost je třeba věnovat podloží na analyzovaných sídlištích. Celkem 11 sídlišt (69 \%) se nacházelo na písku či obecně na říčních písčitých sedimentech, zatímco ostatní typy podloží byly zastoupeny jen okrajově (pararula - 3 lokality, ortorula a migmatit - po 1 lokalitě). Obliba poloh na pískách může do jisté míry souviset s oblibou dnešních ř́ičních niv, ovšem i řada lokalit v jiných polohách byla situována v místech písčitého podloží. Otázkou zůstává, do jaké míry je tato výrazná preference písčitých poloh lokálně a chronologicky specifickou záležitostí. Pro jiné oblasti v jižních Čechách nebyla taková preference písčitých poloh prokázána, i když na písku se nacházelo např. i sídliště v Čavyni u Vodňan (Michálek 2013) a na jílovito-písčitých nivních sedimentech nedaleko písčité terasy byla zjištěna starobronzová kulturní vrstva u Myšence na Písecku (Kuna a kol. 2004, 45-46, obr. V). Ze soudobých lokalit mimo jihočeský region, umístěných na písku, lze zmínit rozsáhlý sídlištní a pohřební areál ve Vliněvsi ve středních Čechách (Limburský a kol. 2018).

Z hlediska chronologické specifičnosti poloh na pískách se nabízí otázka, zdali byla analyzovaná sídliště monokulturní, nebo jestli byla 


\begin{tabular}{|c|c|c|c|c|c|c|c|c|}
\hline Číslo & Lokalita & podloží & $\begin{array}{l}\text { paleolit/ } \\
\text { mezolit }\end{array}$ & eneolit & $\begin{array}{c}\text { střední doba } \\
\text { bronzová }\end{array}$ & halštat & latén & $\begin{array}{c}\text { raný } \\
\text { středověk }\end{array}$ \\
\hline 1 & Borek & písek & $\bullet$ & - & - & - & - & - \\
\hline 2 & Č. Budějovice & písek & - & - & - & - & - & - \\
\hline 3 & Č. Budějovice & písek & - & - & - & - & - & - \\
\hline 4 & Dobřejovice & písek & - & - & - & - & - & - \\
\hline 5 & Dobřejovice & ortorula & $\bullet$ & - & - & - & - & $\bullet$ \\
\hline 6 & Hosty & písek & $\bullet$ & $\bullet$ & - & - & - & - \\
\hline 7 & Hůry & migmatit & - & - & - & - & - & - \\
\hline 8 & Knín - Býšov & pararula & - & - & - & - & - & - \\
\hline 9 & Křtěnov & pararula & - & - & - & - & - & - \\
\hline 10 & Litoradlice & písek & - & - & - & - & - & - \\
\hline 11 & Litvínovice & písek & - & - & - & - & - & - \\
\hline 12 & Planá u ČB & písek & - & - & $\bullet$ & $\bullet$ & - & - \\
\hline 13 & Plav & písek & - & - & - & - & $\bullet$ & - \\
\hline 14 & St. Hodějovice & písek & - & - & $\bullet$ & $\bullet$ & $\bullet$ & $\bullet$ \\
\hline 15 & Týn n. Vlt. & pararula & - & - & - & $\bullet$ & - & - \\
\hline 16 & Vrábče & písek & - & - & - & - & - & - \\
\hline \multicolumn{3}{|c|}{ CELKEM } & 3 & 1 & 2 & 3 & 2 & 2 \\
\hline
\end{tabular}

Tab. 2. Sídelní aktivity z jiných chronologických úseků v prostoru rovinných sídlišt starší a počátku střední doby bronzové na Českobudějovicku.

Tab. 2. Siedlungaktivitäten anderer chronologischen Perioden in den Arealen der Flachlandsiedlungen der Frühbis beginnenden Mittelbronzezeit.

osídlena i v jiných obdobích. Vytvořený přehled (tab. 2) ukazuje jasnou převahu monokulturních lokalit. Na třech sídlištích byly prokázány stopy paleolitických/mezolitických aktivit, na stejném počtu starobronzových sídlišt byla zachycena i halštatská sídelní komponenta. Prostor dvou starobronzových sídlišt byl osídlen i ve střední době bronzové, v době laténské a v raném středověku, jedno sídliště pak přineslo doklad i eneolitického osídlení. Některé z uvedených lokalit se nacházely na pískách, což ukazuje, že lidé se těmto polohám nevyhýbali ani v jiných obdobích, avšak (snad jen s výjimkou mezolitu: Vencl a kol. 2006, 436; Vencl - Fridrich 2007, 125, 144) je patrně nijak výrazněji nepreferovali. Pro relevantní vyhodnocení tohoto jevu by však bylo potřeba provést obdobnou analýzu u všech pravěkých a raně středověkých rovinných sídlišt sledované oblasti. Pro srovnání lze uvést, že západočeská mladobronzová rovinná sídliště byla ve velké míře zakládána na sladkovodních sedimentech, kam patří i písky, štěrkopísky apod. (Hůrková 2002, 22-23, graf 11). Pro starobronzová sídliště na Českobudějovicku je nicméně převažující monokulturní osídlení příznačné, tj. lidé při zakládání převážné většiny rovinných sídlišț v jiných chronologických úsecích pravěku a raného středověku evidentně preferovali jiné polohy. 


\section{Velikost, vnitřní struktura sídlišt' a charakter nemovitých objektů}

Bližšímu poznání vnitřní struktury i nemovitých objektů sledovaných sídlišt brání malá míra prozkoumání velké většiny lokalit. Prakticky všechny byly sice objeveny v posledních čtyřech desetiletích (tab. 1), systematicky odryto však bylo pouze sídliště v Hostech (Beneš 1988; Břicháček 1991). V ploše větší než $100 \mathrm{~m}^{2}$ byla alespoň částečně prozkoumána sídliště v Borku, Českých Budějovicích (č. 3), Kníně, Plavu, Starých Hodějovicích a Vrábči, ostatní byla zachycena jen v malých plochách nebo v řezech.

Z hlediska velikosti analyzovaných lokalit se zdají být odlišitelné dvě skupiny. První zahrnuje lokality o velikosti řádově cca $1-3$ ha, druhou skupinu pak reprezentují polohy o velikostech max. 0,1-0,5 ha. Zdůraznit ovšem musíme skutečnost, že zatím žádné $\mathrm{z}$ analyzovaných sídlišt nebylo odkryto kompletně, následující informace jsou proto jen orientační. Do první skupiny bezesporu patří sídliště v Hostech, zaujímající plochu asi 3 ha (Beneš 1988, 7), která byla zhruba z jedné třetiny prozkoumána. Podobný rozsah měla i rozplavená kulturní vrstva na lokalitě České Budějovice - Dobrovodská stoka, která byla zjištěna na území o velikosti cca 300 $\times 100 \mathrm{~m}$; v tomto případě se však jednalo o erodovanou a sekundárně akumulovanou archeologickou situaci, která nemusela odrážet původní velikost osady. Rovněž v délce cca 300 m byly identifikovány sídlištní artefakty v Borku, širrku plochy sídliště se však zjistit nepodařilo. V přibližně stejné ploše max. $300 \times 100 \mathrm{~m}$ byly zjištěny i pravěké objekty sídliště u Starých Hodějovic, přesnější stanovení rozsahu starobronzové komponenty však bude možné až po zpracování a chronologickém zařazení jednotlivých objektů. Do druhé skupiny patří sídliště v Kníně - Býšově, jehož předpokládaný rozsah lze stanovit na základě plošného odkryvu na cca $30 \times 25 \mathrm{~m}, \mathrm{tj} .750 \mathrm{~m}^{2}$, v tomto př́padě se tedy mohlo jednat o lokalitu zahrnující patrně jedinou usedlost. Podobnou plochu cca $20 \times 40 \mathrm{~m}$ $\left(800 \mathrm{~m}^{2}\right)$ zaujímaly i objekty zachycené v pískovně ve Vrábči, přičemž v dalších skrytých plochách nebyly žádné další pravěké situace nalezeny. V Plavu bylo starobronzové sídliště zjištěno na ploše cca $60 \times 40 \mathrm{~m}\left(2400 \mathrm{~m}^{2}\right)$, ovšem i tato lokalita byla prozkoumána jen částečně.

$\mathrm{Z}$ analyzovaných lokalit poskytlo nejvíce informací o vnitřní struktuře sídliště v Hostech. Především díky výzkumům v posledních dvou sezónách (1987-1988) se zde podařilo prokázat jednak řadu staveb kůlové konstrukce, které byly rozptýlené po celé zkoumané ploše výzkumu, a jednak část opevnění osady, tvořené dvěma nesoučasnými příkopy o šířce 2 a $4 \mathrm{~m}$ a hloubce 2 m (obr. 3:A; Břricháček 1991, fig. 2). Jiné doklady opevnění ani ohrazení nebyly na rovinných sídlištích nejen v jihočeském regionu, ale i v sousedních regionech hornodunajské kulturní oblasti prokázány (srov. Chvojka 2011, 19). Z dalších sledovaných lokalit poskytla data k vnitřní zástavbě jen některá: celkem pravidelný rozptyl objektů byl zjištěn na sídlišti v Kníně - Býšově (Chvojka - Zavřel 2011), zatímco na sídlištích ve Starých Hodějovicích a ve Vrábči byly objekty koncentrovány spíše do malého prostoru a jiné plochy na nich byly prázdné. V Plané u Českých Budějovic byla větší část skrývky bez nálezů, dva starobronzové objekty se nacházely na opačných koncích skryté plochy ve vzdálenosti cca $90 \mathrm{~m}$.

Vzhledem k malému rozsahu dosud provedených výzkumů bylo na analyzovaných lokalitách zatím zachyceno jen malé množství sídlištních objektů. Dvě sídliště poskytla doklady kůlových/sloupových staveb povrchové konstrukce. V Hostech zachytil P. Břicháček v závěrečných sezónách výzkumu minimálně 12 domů o rozměrech od 4,3 × 4,8 m do 11,5 × 7,5 m (obr. 3:B), v jejichž okolí se nacházely zásobní jámy (Břicháček 1991, 90). Druhým jihočeským rovinným sídlištěm s nálezem snad 

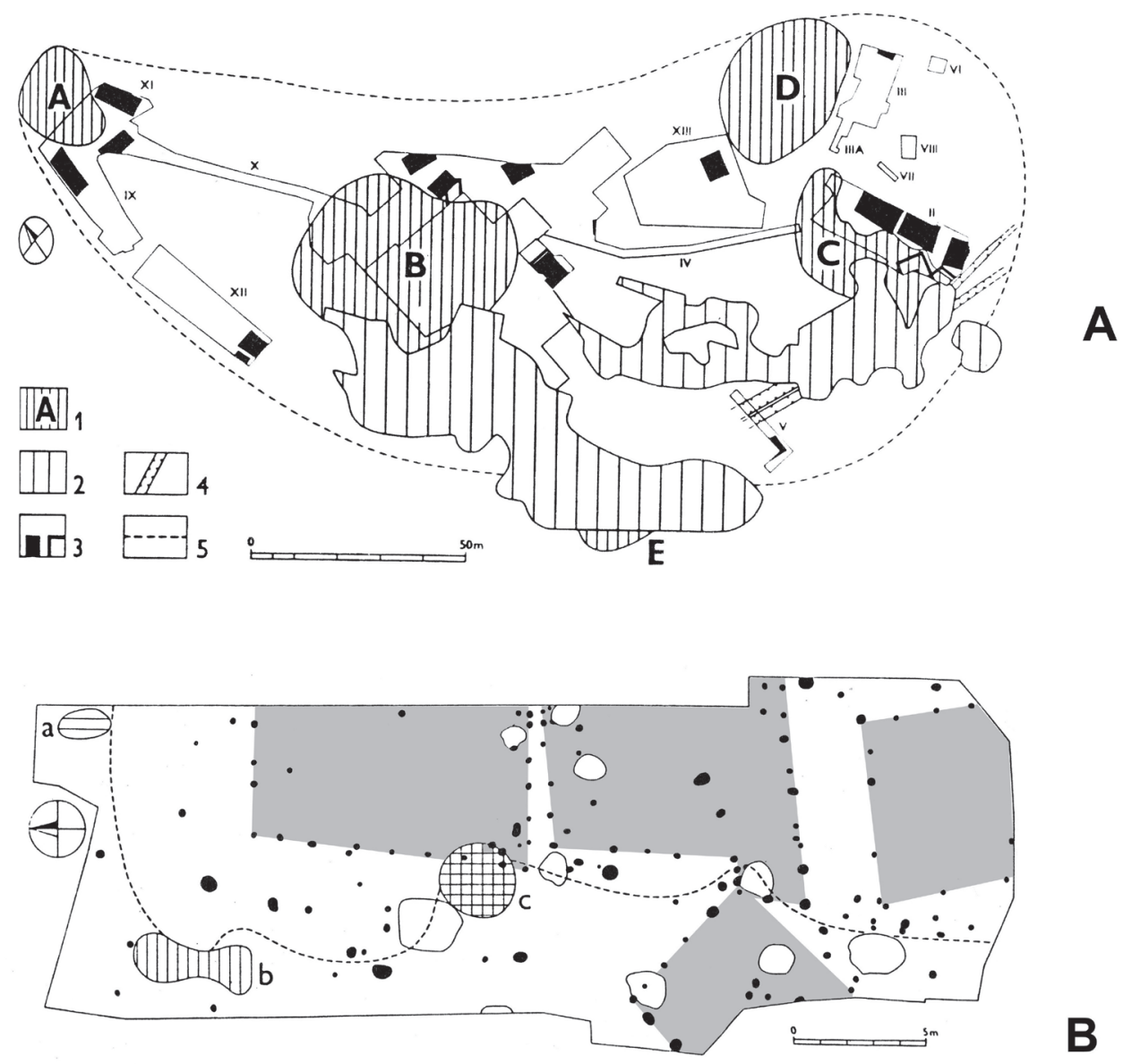

B

Obr. 3. Hosty. A - plán sídliště s půdorysy domů a se dvěma př́kopy; B - sonda II/87/88 s půdorysy několika staveb kưlové konstrukce. Podle Břicháček 1991, fig. 1-2.

Abb. 3. Hosty. A - Plan der Siedlung mit Hausgrundrissen und mit zwei Gräben; B - Grabungsschnitt II/87/88 mit Grundrissen einiger Pfostenbauten. Quelle: Břicháček 1991, fig. 1-2.

obytného objektu je sídliště v Kníně - Býšově. Ačkoliv nebylo nikde zachyceno žádné otopné zařízení, nelze v případě kumulace objektů č. 3, 7, 13 a několika menších jamek mezi nimi (obr. 4) vyloučit, že se jedná o zbytek obytného objektu s mírně zapuštěnou podlahou (objekt 7/05), spojenou do jednoho celku (pod jednou střechou? - srov. kumulace kůlových jamek) patrně s hospodářským přístavkem (objekt 3/05).
Jiný objekt s mírně zahloubenou podlahou byl zjištěn na sídlišti v Hůrách - obdélnou „chatu“ o rozměrech $8 \times 3 \mathrm{~m}$, mírně $(20 \mathrm{~cm})$ zahloubenou do podloží, lemovalo 7 jam. Jako zahloubenou chatu označili autoři výzkumu i objekt č. 45 na sídlišti u Starých Hodějovic (Militký - Zavřel 1995, 56). Jednalo se o oválnou jámu s lalokovitým výčnělkem v SV rohu, s téměř kolmými stěnami a rovným dnem o rozměrech $360 \times 270 \mathrm{~cm}$ a hloubce max. $36 \mathrm{~cm}$. K jednoznačné interpre- 


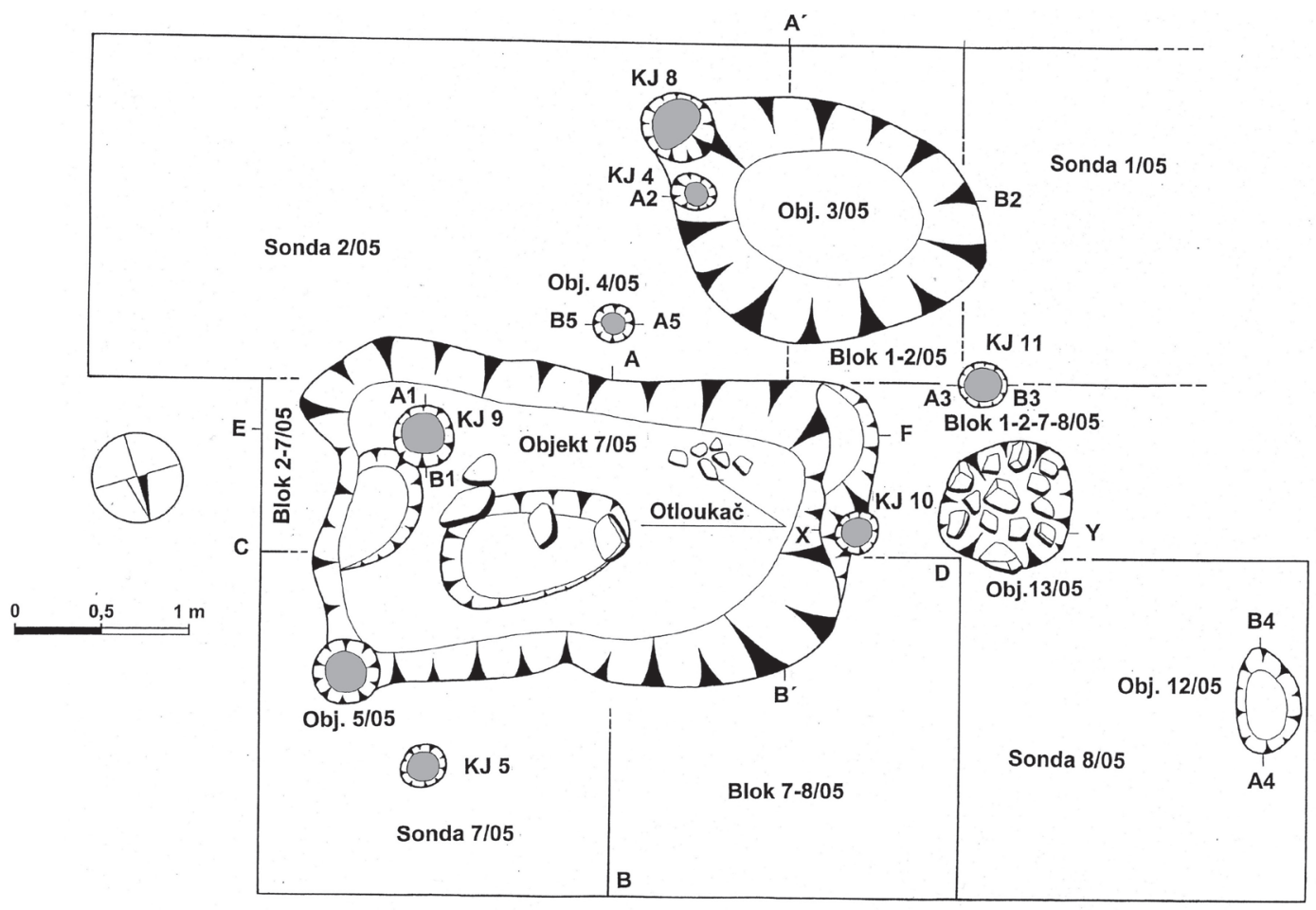

Obr. 4. Knín - Býšov. Kumulace jam a kůlových jamek, tvořících snad obytný objekt. Podle Chvojka-Zavřel 2011, obr. 5.

Abb. 4. Knín - Býšov. Eine Akkumulation von Gruben und Pfostenlöchern, die vielleicht ein Haus gebildet haben. Quelle: Chvojka - Zavřel 2011, obr. 5.

taci obou těchto objektů jako zemnic jim však chybějí především doklady otopných zařízení. Dalším výraznějším zahloubeným objektem je jáma obdélného tvaru se zaoblenými nárožími o rozměrech $3,4 \times 2,3 \mathrm{~m}$ a hloubce max. $40 \mathrm{~cm}$ a se dvěma kůlovými jamkami při J a SV okraji objektu, která byla prozkoumána na sídlišti v Plané u Českých Budějovic (obr. 5). Ani tento objekt nemůžeme ovšem označit za jednoznačný doklad zahloubené chaty.

Z jižních Čech je známa také jedna povrchová stavba vymezená kameny. Na sídlišti v Hostech zjistil A. Beneš dvě řady kamenů severojižní orientace o délce 9,4 $\mathrm{m}$ a šířce 2,15 až 2,50 m, mezi nimiž bylo nalezeno množství drobných keramických plastik, bronzových ná- lezů aj. (Beneš 1988, 9). Podle autora výzkumu se jednalo o astronomicky orientovanou stavbu zvláštního významu (Beneš 1989, 227-228). Na tomto sídlišti bylo zachyceno i několik dokladů zásobních jam. Některé byly rozptýlené v areálu sídliště (Beneš 1988, 9), jiné byly vázané na přítomnost staveb kůlové konstrukce, před nimiž se nacházely (Břicháček 1991, 90). Jiné zásobní jámy ze starší doby bronzové nejsou v jižních Čechách známy.

Zásobní funkci mohlo snad mít i torzo solitérního keramického hrnce, jehož dno bylo mírně zapuštěno do podloží, nalezené na sídlišti v Plané u Českých Budějovic (obr. 5). Jiné doklady solitérních zapuštěných nádob z tohoto období ve sledované oblasti postrádáme. 

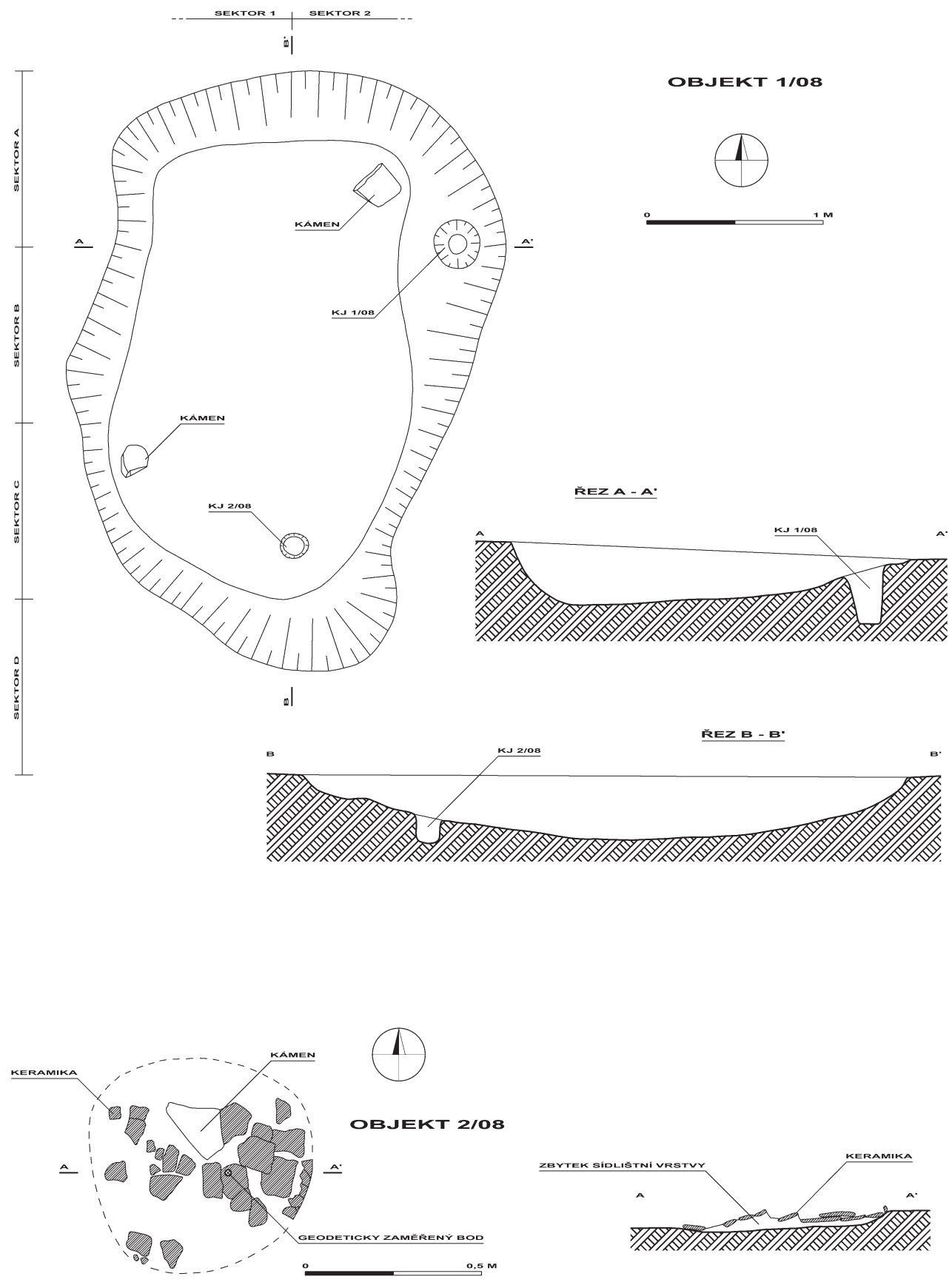

Obr. 5. Planá u Českých Budějovic. Objekty 1 a 2/08. Podle Chvojka 2011, Tab. 20.

Abb. 5. Planá bei České Budějovice. Befunde 1 und 2/08. Quelle: Chvojka 2011, Tab. 20. 
Na mnoha sídlištích je doložena řada běžných sídlištních jam, u nichž většinou nelze určit jejich původní funkci, některé však mohou přinést doklady o výrobních činnostech na sídlišti. Příkladem je sídliště v jihočeském Kníně - Býšově, na němž bylo identifikováno celkem 12 zahloubených objektů a 11 kůlových jamek, z nichž některé tvořily součást větších zahloubených objektů. Vedle běžných jam lze podrobněji zmínit dva interpretačně významnější objekty: objekt 1/05 se třemi kůlovými jámami při jižním obvodu měl, vzhledem ke zmíněným nálezům mazanice v jeho okolí, nepochybně nadzemní dřevo-hlinitou konstrukci (obr. 6:A). Zajímavý byl dále objekt č. 8/05 s kamennou kumulací ve své výplni, který lze na základě nálezu kamenné zrnotěrky (podložky) a několika otloukačů interpretovat jako výrobní objekt, související pravděpodobně s úpravou obilí (obr. 6:B).

$\mathrm{Na}$ mnoha jihočeských sídlištích byly nalezeny solitérní či rozptýlené jámy, o jejichž původním účelu není možné prakticky nic sdělit. Ojedinělé jámy jsou doloženy ze sídlišt v Dobřejovicích, Borku či v Plavu. Na sídlišti ve Starých Hodějovicích bylo sice prozkoumáno několik desítek jam, do starší doby bronzové však lze bezpečně zařadit jen několik. Celkem 12 bezpečně datovaných jam poskytlo sídliště ve Vrábči.

Zajímavou nálezovou situaci poskytlo sídliště u Borku. Zde byla prozkoumána větší (min. $11 \times 19 \mathrm{~m}$ ) patrně přirozená prohlubeň vyplněná neobvykle velkým množstvím velice kvalitní a mimořádně dobře dochované keramiky i dalších nálezů. Objekt byl patrně lidmi využíván k ukládání odpadu a následně, patrně po opuštění sídliště, byl postupně zaplněn erodovanou kulturní vrstvou z výše položených partií sídliště a dalšími splachy.

Na řadě jihočeských sídlišt byla zachycena kulturní vrstva. Klasickou je v tomto smyslu lokalita v Hostech, kde byla doložena vrstva o mocnosti až $40 \mathrm{~cm}$, která obsahovala velmi početné nálezy, tvořící místy i výrazné kumulace (shrnutí viz Ernée 2008, 38-41). Přestože sídliště bylo vícefázové, nebylo možné v rámci uvedené kulturní vrstvy odlišit případnou vertikální stratigrafii. Především na základě sídlištní vrstvy bylo identifikováno sídlišstě v Kníně - Býšově. Vrstva měla mocnost většinou mezi $20-25 \mathrm{~cm}$, výjimečně přesahovala i $30 \mathrm{~cm}$. Místy byla částečně narušena provedenou skrývkou ornice, vcelku však zůstala nenarušena. Ze sídlištní vrstvy pochází většina (plných 80 \%) nalezených artefaktů (Chvojka - Zavřrel 2011). Podobně i na sídlišti v Plavu byla velká většina artefaktů obsažena v písčité kulturní vrstvě, mocné zhruba 30-40 cm (obr. 7). Jen v krátkých zmínkách jsou uvedeny nálezy kulturních vrstev na sídlištích v Dobřejovicích (č. 5), Křtěnově, Litoradlicích a v Týně nad Vltavou.

Další jihočeská sídliště, ležící v nivních oblastech, poskytla erodované a naakumulované kulturní vrstvy. Jedná se o sídliště v Českých Budějovicích - Dobrovodské stoce (obr. 8), Českých Budějovicích - Čalounově zahradě a v Litvínovicích. Tyto kulturní vrstvy, obsahující keramické nálezy i početné organické (především dřevěné) zbytky, se nacházely pod mocnými splachovými souvrstvími v hloubkách přesahujících $1 \mathrm{~m}$ od dnešního povrchu. Přestože se ve všech těchto př́ípadech jedná o druhotně transformované vrstvy, poskytly velice zajímavé doklady movitých artefaktů i ekofaktů (srov. např. Jankouská 2001; Pokorný a kol. 2002, 816, 818).

\section{Chronologie sídlišt'}

V nedávné době byla epocha starší a počátku střední doby bronzové v jižních Čechách rozdělena do čtyř fází (Hlásek - Chvojka 2019). Většinu sídlišt však takto precizně zatím zařadit nelze, nebot obvykle málo výrazné sídlištní nálezy jemnější chronologii zpravidla neumožňují. 

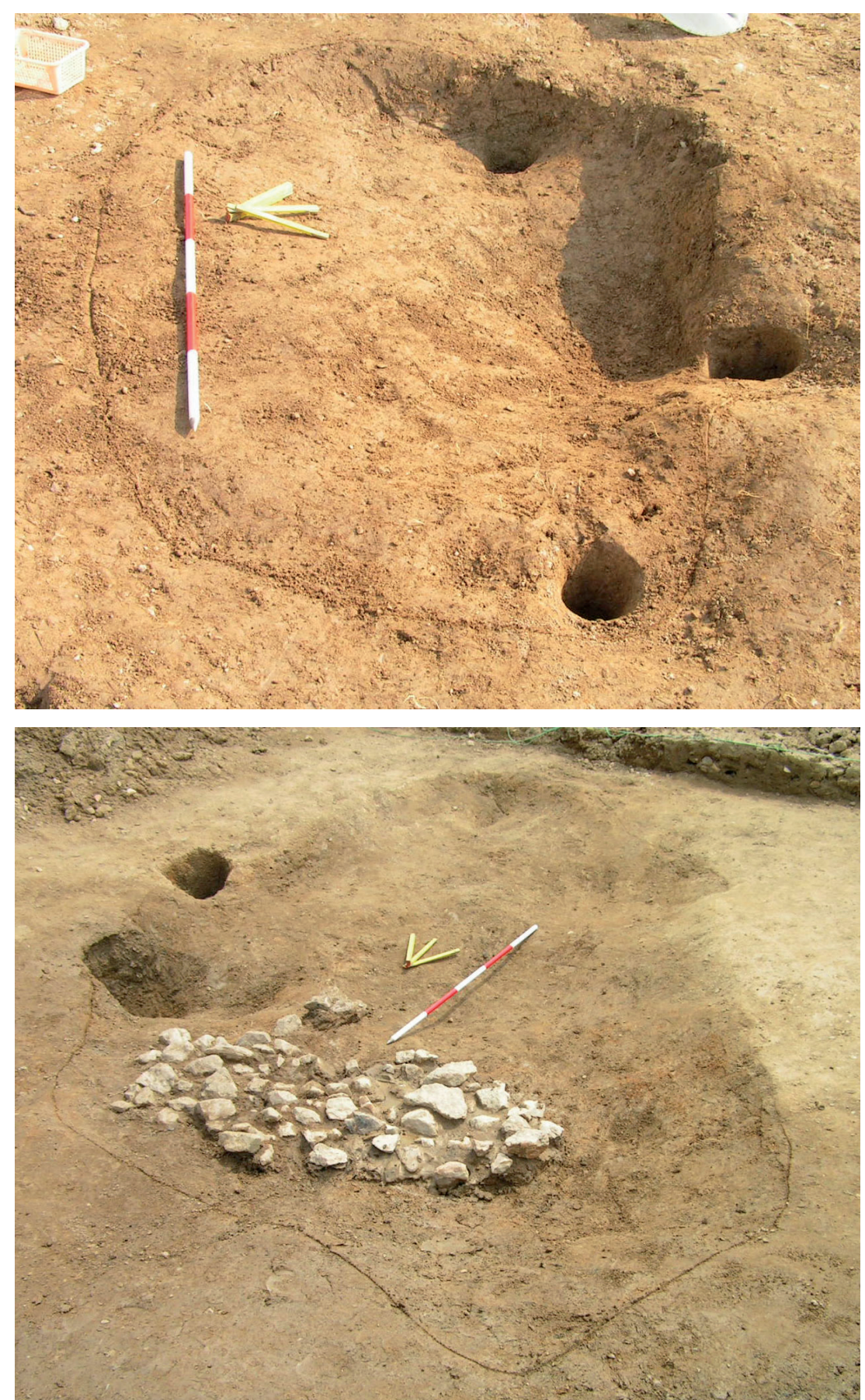

Obr. 6. Knín - Býšov. Př́klady sídlištních objektů. A - objekt 1/05, B - objekt 8/05. Podle Chvojka - Zavřel 2011, obr. 10, 12.

Abb. 6. Knín - Býšov. Beispiele von Siedlungsbefunden. A - Befund 1/05, B - Befund 8/05. Quelle: Chvojka Zavřel 2011, obr. 10, 12. 


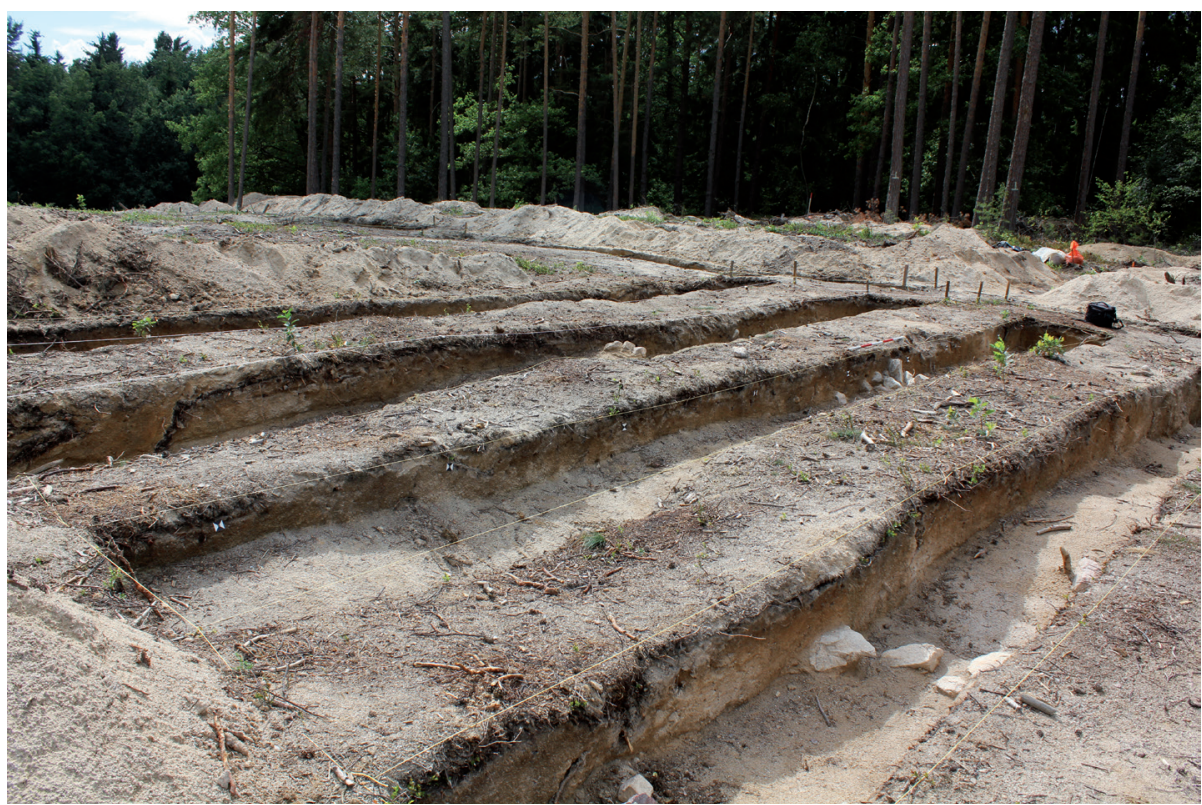

Obr. 7. Plav. Archeologický výzkum písčité kulturní vrstvy v roce 2018. Foto O. Chvojka.

Abb. 7. Plav. Archäologische Untersuchung der sandigen Kulturschicht im Jahr 2018. Foto O. Chvojka.
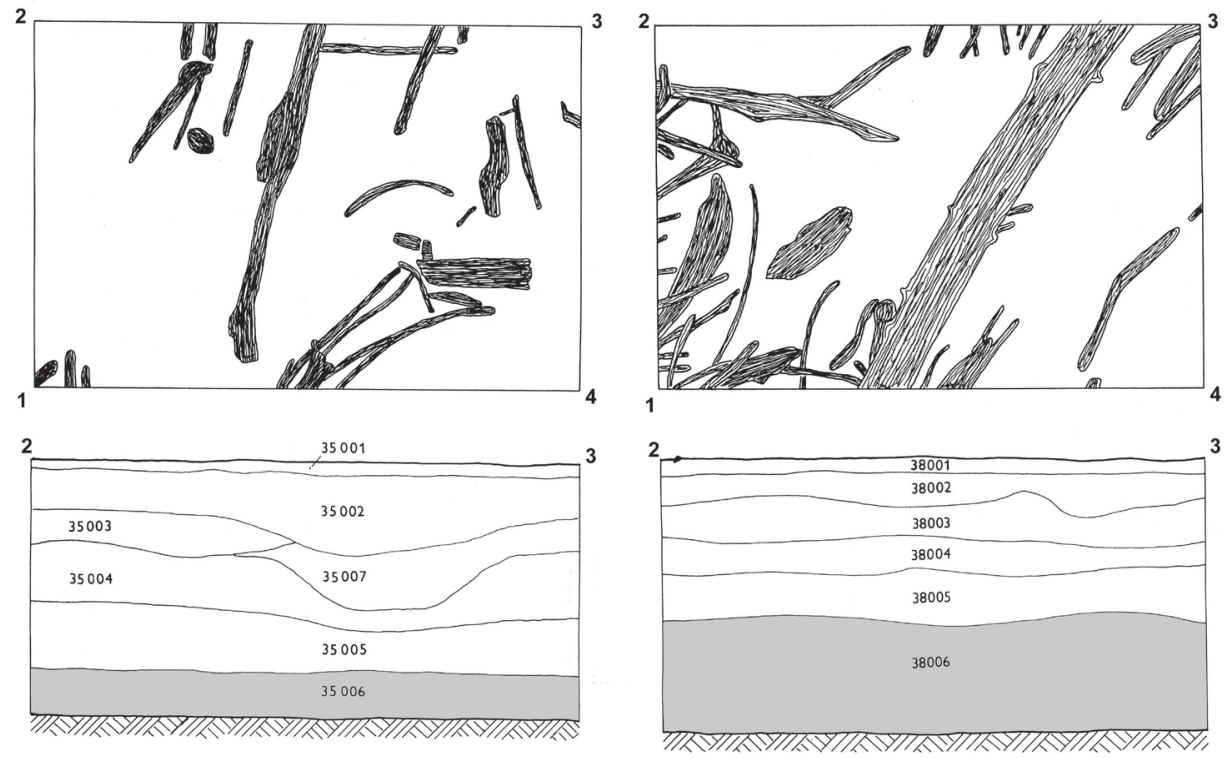

Sonda $35 / 95$

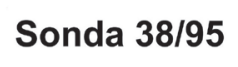

Obr. 8. České Budějovice - Dobrovodská stoka. Ukázka stratigrafie lokality s erodovanou a naakumulovanou kulturní vrstvou nad podložím, obsahující četné organické zbytky. Podle Chvojka 2011, Tab. 3.

Abb. 8. České Budějovice - Dobrovodská stoka. Stratigraphie der Fundstelle mit erodierter und akkumulierter Kulturschicht oberhalb der Sohle, mit zahlreichen organischen Resten. Quelle: Chvojka 2011, Tab. 3. 
Řada dalších lokalit pak bude blíže zařaditelná až po svém zpracování. Z podrobněji sledovaných 16 sídliš̌t na Českobudějovicku je v tuto chvíli možné přesněji chronologicky zařadit jen čtyři.

Do nejstarší fáze jihočeské starší doby bronzové, tj. Br A1/A2, lze s určitou opatrností datovat pouze sídliště v Českých Budějovicích Čalounově zahradě (Zavřel 1993, obr. 9; Hlásek - Chvojka 2019, 61). Daleko více dokladů osídlení spadá v jižních Čechách do fáze Br A2, z rovinných sídlišt sem však lze zařadit $\mathrm{s}$ jistotou jen jediné - starší fázi sídliště v Hostech (Beneš 1988, 11; Břicháček 1991, 90, 93). Tato lokalita byla osídlena (kontinuálně?) i v následující třetí fázi $\mathrm{Br} \mathrm{A} 2 / \mathrm{B} 1^{1}$, kam můžeme zároveň bezpečně datovat i nedávno zkoumané sídliště u Borku. Vedle většího množství typické keramiky (obr. 9) podporuje dataci tohoto sídliště i získané radiokarbonové datum $3430 \mathrm{BP} \pm 25$ (po kalibraci 1876-1630 BC, s pravděpodobností 95,4 \%; Chvojka - Šálková - Š́da a kol. 2021). Snad do stejné fáze náleží i sídliště v Českých Budějovicích - Dobrovodské stoce, jak naznačují dvě radiokarbonová data $1714 \pm 136$ BC a $1634 \pm 135$ BC (Jankovská 2001). Do raně středobronzové fáze $\mathrm{Br} \mathrm{B} 1$ zatím nelze bezpečně zařadit žádné rovinné sídliště na Českobudějovicku.

\section{Sídelně-prostorová analýza}

Analyzovaná starobronzová rovinná sídliště vytvářejí dva prostorově oddělené shluky (obr. 2) - severnější na Vltavotýnsku a jižnější v širším okolí dnešních Českých Budějovic. Do jaké míry odrážejí tyto koncentrace původní sídelní komory, nebo jen aktuální stav poznání tohoto typu památek, je otázkou dalšího výzkumu. Vzhledem $\mathrm{k}$ absenci podrobnější datace většiny lokalit nelze bohužel určit jejich případné vzájemné vztahy. Nápadně působí pouze blízkost dvou sídlišt v Českých Budějovicích - Čalouno- vě zahradě (č. 2) a Litvínovicích (č. 11), která jsou od sebe vzdálená cca $500 \mathrm{~m}$, a nelze tak u nich vyloučit, že byla součástí jednoho sídelního areálu.

Z hlediska prostorové vazby mezi rovinným a výšinným sídlištěm lze uvést blízkost sídliště v Hostech a nedalekých tř́i hradišt (Týn nad Vltavou - Sv. Anna, Všemyslice - Kozí vrch, Albrechtice - Holý vrch), ačkoliv časová současnost všech těchto lokalit není jistá (srov. nejnověji Hlásek 2020, 54-55). Sídliště u Dobřjovic (č. 5) je vzdáleno přibližně $1 \mathrm{~km}$ od starobronzového hradiště na návrší Hradec (Chvojka - John - Šálková 2008) a zhruba 1,7 km od dalšího hradiště na návrší Baba u Hluboké nad Vltavou (Chvojka - John 2006). Ani u těchto lokalit ovšem není jisté, jestli byly osídlené v jednom okamžiku. Další sledovaná rovinná sídliště na Českobudějovicku jsou od (soudobých?) starobronzových hradišt více vzdálená, o přímé prostorové vazbě tak u nich nelze uvažovat.

Rovinná sídliště starší doby bronzové na Českobudějovicku nemají ani přímou prostorovou vazbu na soudobá pohřebiště, která jsou v této době v jižních Čechách pouze mohylová (Chvoj$k a-$ Menšik 2020). Většina sídlišt je od jistých starobronzových mohyl vzdálena min. několik kilometrů (nejmenší vzdálenost zhruba $2 \mathrm{~km}$ je mezi sídlištěm v Hostech a mohylníkem na stejném katastru; srov. Beneš 1988, obr. 1). Výjimku v tomto směru představuje sídliště v Křtěnově, na němž měly být budovány soudobé starobronzové mohyly (Braun 1987, 251); otázku případné následnosti či současnosti obou uvedených komponent by ovšem mohl prokázat pouze zatím neprovedený podrobný rozbor artefaktů i celé nálezové situace této lokality. Za zmínku v této souvislosti stojí i přítomnost starobronzové sídlištní keramiky v násypech mohyl ze střední doby bronzové v Plavu; sídliš̌tě ze starší doby bronzové zde ovšem jednoznačně časově předcházelo mladšímu mohylovému pohřebišti (Chvojka - Zavřrel v tisku). 

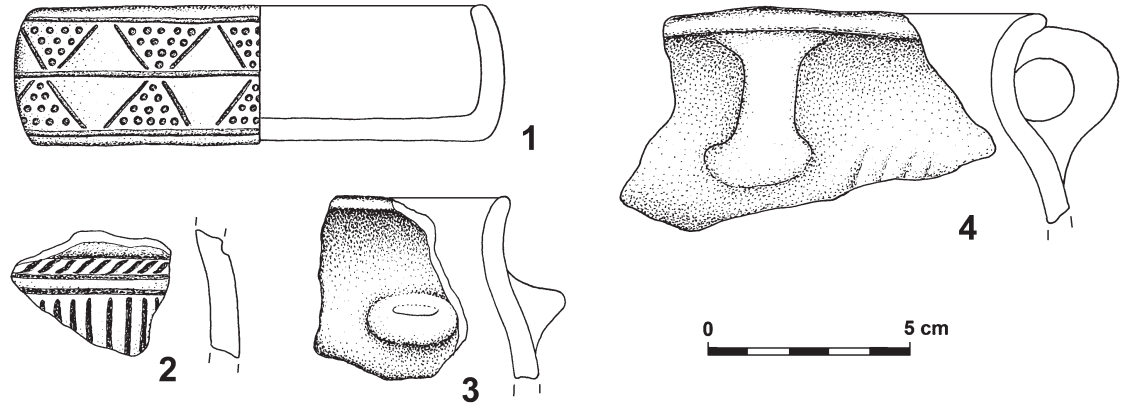

3
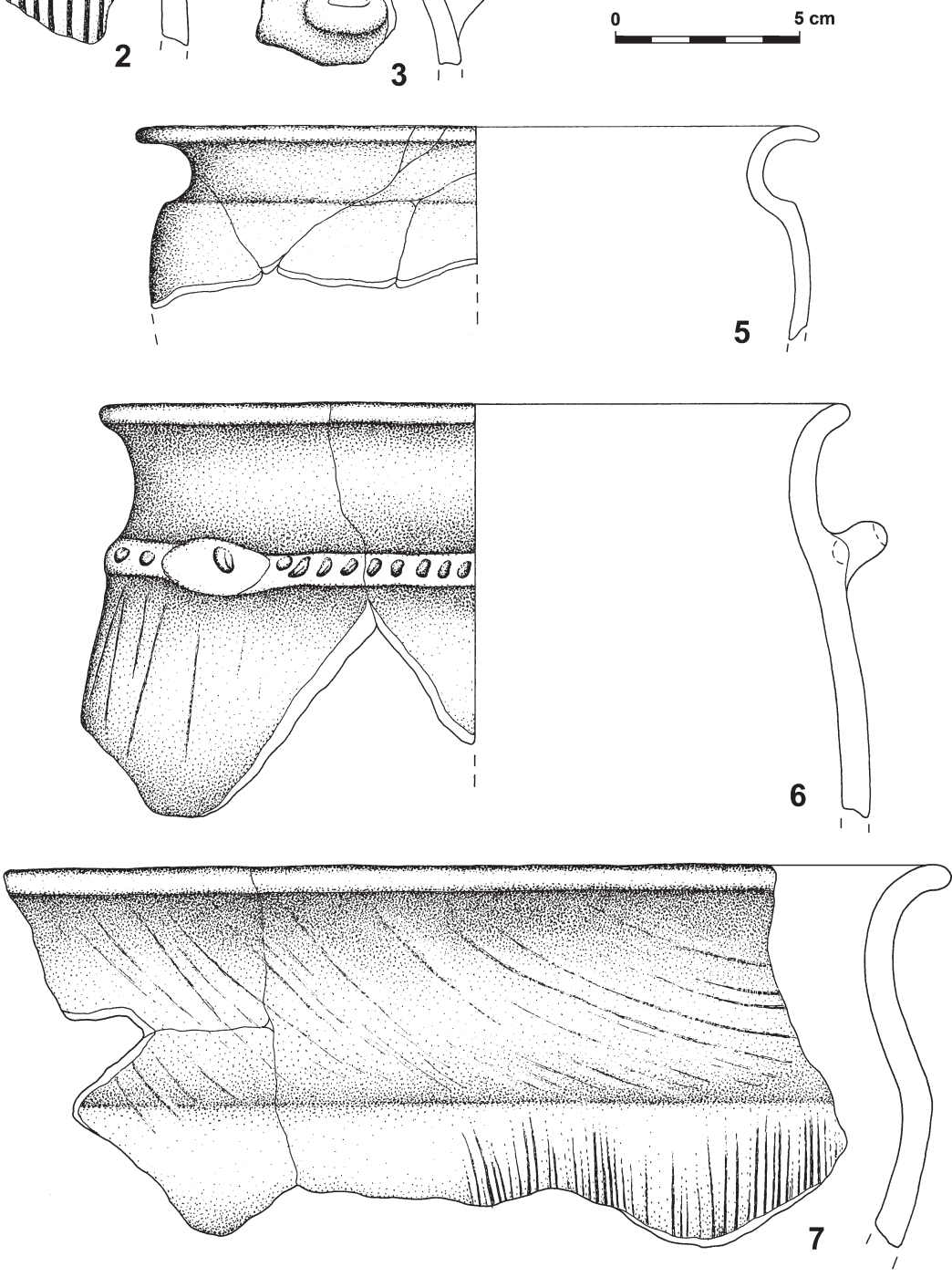

Obr. 9. Borek. Výběr keramických nálezů ze sídliště. Podle Chvojka - Šálková - Šída a kol. 2021.

Abb. 9. Borek. Auswahl von Keramikfunden aus der Siedlung. Quelle: Chvojka - Šálková - Šída a kol. 2021. 
Prozatím se nepodařilo prokázat žádnou vazbu mezi sledovanými rovinnými sídlišti a depoty kovových artefaktů, které jsou jinak v této oblasti značně početné (srov. Chvojka 2015b). Obecně platí, že velká většina kovových depotů starší a počátku střední doby bronzové pochází z poloh mimo soudobá sídliště či pohřebiště, přičemž z areálů rovinných sídlišț jsou v jižních Čechách dosud známy jen dva depoty žeber (Kučeř a s výhradami Kroclov: Chvojka a kol. 2018b, 227, tab. 7).

\section{Diskuse a závěr}

Vrátíme-li se k otázkám, nastoleným v úvodu tohoto článku, lze na ně za současného stavu poznání odpovědět následovně:

- Co maji pojednávaná sídliště společného a v čem se odlišuji? Společná je především vazba těchto sídlišt na řeku Vltavu, která tehdy představovala významný dálkový obchodní koridor. Odlišují se zejména mírou prozkoumání, která v tuto chvíli znemožňuje bližší porovnání jejich vnitřních struktur, charakteru nemovitých objektů i stanovení bližší chronologie jednotlivých lokalit. Podle dnešního stavu poznání se jako zcela mimořádná jeví být lokalita u Hostů, lišící se v mnoha směrech od ostatních soudobých rovinných sídlišt'.

- Jsou sledovaná sídliště něčm specifická z topografického hlediska? Velká část lokalit se nachází v dnešních nivách ( $t a b .1)$ a více než dvě třetiny leží na písčitém podloží ( $t a b .2)$. Právě poloha většiny sídlišt na písčitých sedimentech je v této oblasti specifická a bude vyžadovat další pozornost.

- Existuji na analyzovaných sídlištich doklady specializované výroby či napojeni na dálkový obchod? Jedinou lokalitu s doklady specializované výroby představují Hosty s prokázanou metalurgickou aktivitou (tyglíky, zlomek kadlubu, zlomek mě- děné hřivny, slitky). Častější jsou na sledovaných lokalitách doklady dálkového obchodu, představující např. nálezy jantaru (Hosty, Borek, Plav?). Dálkové kontakty naznačují i některé keramické tvary či výzdoba keramiky, a to opět především na sídlišti v Hostech, v ojedinělých případech však i na dalších lokalitách (např. Borek, České Budějovice - Čalounova zahrada). Na úzkou vazbu na dálkovou obchodní trasu ukazuje poloha sledovaných sídlišt v trase vltavského koridoru.

- Lze vysledovat vztah analyzovaných sidlišt’ $k$ soudobým hradištim, pohřebištím či dalšim areálům lidských aktivit? Jak bylo podrobněji pojednáno výše, většina sledovaných rovinných sídlišt přímou vazbu na další soudobé lokality nevykazuje. Všechna sídliště se ovšem nacházejí v poměrně hustě osídlené krajině s doklady mnoha desítek pohřebišt', hradišt či depotů.

- Je Českobudějovicko z hlediska sídelnich strategii odlišné od okolnich oblasti? Sledovanou oblast, označenou v tomto článku jako „Českobudějovicko“, můžeme rozdělit do dvou sídelních komor (jižní část Českobudějovické pánve v širším okolí soutoku Vltavy a Malše a Vltavotýnsko vokolí soutoku Vltavy a Lužnice). V obou uvedených komorách se jeví být sídelní strategie této epochy obdobné, kdy byla většina lokalit orientována na vltavský koridor. V tomto směru je Českobudějovicko obdobné $\mathrm{k}$ dalším mikroregionům $\mathrm{v}$ jižních Čechách, kde je osídlení většinou rovněž vázáno $k$ hlavním vodním tokům.

Rovinná sídliště patřila dlouhou dobu k opomíjeným památkám většiny pravěkých archeologických kultur. Nejinak tomu bylo i v jižních Čechách, kde až do poloviny 20. století nebyl tento druh památek pro starší dobu bronzovou prakticky vůbec znám (srov. Hájek 1954). Situace se začala lepšit až od 60. let 20. století, na Českobudějovicku pak až od 80. let, kdy probíhal především stěžejní dlouhodobý výzkum 
sídliště v Hostech. V posledních letech pak při- Vrábče, Knín - Býšov, Borek, Plav, Staré Hoděbylo několik dalších sídlišt', částečně odkrytých jovice). Velká část těchto lokalit však byla publipři záchranných archeologických výzkumech kována zatím jen předběžně a na své podrobné (např. České Budějovice - Dobrovodská stoka, zpracování teprve čeká.

1) V nedávné době byla existence této fáze podrobena kritice (Benkovsky-Pivovarová - Stadler 2019), v jižních Čechách ji však lze bezpečně odlišit jak od „mladoúnětické“ fáze Br A2, tak i od následující „staromohylové“ fáze Br B1 (srov. nejnověji Vondrovský - Chvojka eds. 2021).

\section{Bibliografie}

Beně̌, A. 1981: Dobřejovice, Vrábče, Výzkumy v Čechách 1976-1977, 28, 159.

Beně̌, A. 1984: Pravěká osada z doby bronzové na soutoku Lužnice a Vltavy. Předstihový archeologický výzkum v Hostech 1981-1983. Týn nad Vltavou.

Beneš, A. 1988: Sídliště ze starší doby bronzové u Hostů, okres České Budějovice. Zpráva o předstihovém výzkumu za léta 1981-1985, Archeologické výzkumy v jižních Čechách 5, 7-26.

Beněs, A. 1989: Hosty: Die südböhmische frühbronzezeitliche Siedlung unter Teilnahme der karpatenländlichen Kulturen. Praehistorica 15, 227-232.

Beneš, A. - Michálek, J. - Zavřel, P. 1999: Archeologické nemovité památky okresu České Budějovice. Praha.

Beneš, J. 1995: Erosion and accumulation processes in the late holocene of Bohemia, in relation of prehistoric and medieval landscape occupation. In: Kuna, M. - Venclová, N. (eds.), Whither archaeology? Papers in honour of Evžen Neustupný. Praha, 133-144.

Benkovsky-Pivovarová, Z. - Stadler, P. 2019: Der bronzezeitliche „Übergangshorizont A2/B1“ aus der Sicht der Věteřov-Kultur, Pravěk NŘ 27, 43-74.

Braun, P. 1987: Vorgriffsausgrabungen auf dem Atomkraftwerk Temelín, Südböhmen. In: Černá, E. (ed.), Archäologische Rettungstätigkeit in den Braukohlengebieten und die Problematik der Siedlungs-geschichtlichen Forschung. Symposium Most 1986. Praha, 251-253.

Braun, P. 1995: Litoradlice, Výzkumy v Čechách 1990-1992, 187.
Břicháček, P. 1989: Týn nad Vltavou, Výzkumy v Čechách 1986-1987, 206.

Břicháček, P. 1991: Hosty (district of České Budějovice) an Enclosed Settlement of the Early Bronze Age. In: Archaeology in Bohemia 1986-1990. Praha, 90-94.

Břicháček, P. 1992: Dobřejovice, Litoradlice, Výzkumy v Čechách 1988-1989, 28, 87.

Ernée, M. 2008: Pravěké kulturní souvrství jako archeologický pramen. Památky archeologické - Supplementum 20. Praha.

Hájek, L. 1954: Jižní Čechy ve starší době bronzové, Památky archeologické 45, 115-192.

Havlice, J. 2001: Pohřební ritus starší doby bronzové v jižních Čechách, Archeologické výzkumy v jižních Čechách 14, 57-64.

Hlásek, D. a kol. 2015: Vrcovice. Hradiště z počátku střední doby bronzové. Archeologické výzkumy v jižních Čechách - Supplementum 10. České Budějovice - Plzeň.

Hlásek, D. 2020: Pravěká minulost hradiště Holý vrch u Albrechtic nad Vltavou, Archeologické výzkumy v jižních Čechách 33, 45-57.

Hlásek, D. - Chvojka, O. 2019: The Beginning of the Bronze Age in South Bohemia, Studia Hercynia XXIII/2, 54-72.

Hůrková, J. 2002: Rovinná sídliště milavečské kultury v západních Čechách - I. část, Sborník Západočeského muzea v Plzni - Historie 16, 9-101.

Chvojka, O. 2007: Současný stav poznání doby bronzové v jižních Čechách. In: Chvojka, O. - Krajíc, R. (eds.), Archeologie na pomezí. Sborník příspěvků ze semináře. České Budějovice, 8. 11. 2007. Archeologické výzkumy v jižních Čechách - Supplementum 4. České Budějovice, 29-55. 
Chvojka, O. 2011: Rovinná sídliště doby bronzové v hornodunajském kulturním okruhu. Rukopis habilitační práce. FF MU Brno.

Chvojka, O. 2015a: Možnosti rekonstrukce dálkových komunikací i lokálních stezek v době bronzové v jižních Čechách. In: Kubů, F. - Parkman, M. (eds.), Staré stezky. Sborník příspěvků z konference o výzkumu starých komunikací. Prachatice 9. - 11. 6. 2010. Zlatá stezka - Supplementum 1. Prachatice, 115-127.

Chvojka, O. 2015b: Bronzezeitliche Metallhortfunde in Südböhmen. Aktueller Forschungsstand, Fines Transire 24, 49-65.

Chvojka, O. a kol. 2018a: Chvojka, O. - John, J. - Šída, P. - Zavřel, P., Pravěk Blanského lesa. České Budějovice.

Chvojka, O. a kol. 2018b: Chvojka, O. - Menšík, P. Houfková, P. - Šálková, T., K depotům měděných žeber ze starší doby bronzové v sídlištním kontextu: Depot z Kučeře (okr. Písek) pohledem archeologie a archeobotaniky, Archeologické rozhledy 70, 195-238.

Chvojka, O. - John, J. 2006: Hradiště Baba u Hluboké nad Vltavou, Archeologické výzkumy v jižních Čechách 19, 23-41.

Chvojka, O. - John, J. - Šálková, T. 2008: Hradec u Dobřejovic (okr. České Budějovice). Hradiště ze starší doby bronzové, Archeologické výzkumy v jižních Čechách 21, 59-77.

Chvojka, O. - Menšik, P. 2020: Mohylová pohřebiště starší a střední doby bronzové v jižních Čechách. Kontinuita nebo diskontinuita využívání pohřebních areálů? In: Kozubová, A. - Makarová, E. - Neumann, M. (eds.), Scientia antiquitatis est tamquam alter idem. Venované Jozefovi Bátorovi k 70. narodeninám. Slovenská archeológia Supplementum 1. Nitra, 247-256.

Chvojka, O. - Šálková, T. - Š́da, P. a kol. 2021: Sídliště ze závěru starší doby bronzové u Borku. In: Vondrovský, V. - Chvojka, O. (eds.), Kontinuita pravěkých komunit vnitřní periferie? Vývoj osídlení jižních Čech od 9. do počátku 1. tisíciletí př. Kr. České Budějovice, v tisku.

Chvojka, O. - Zavřel, P. 2009: Archeologické výzkumy Jihočeského muzea v roce 2008. In: Archeologické výzkumy v Čechách 2008. Sborník referátů z informačního kolokvia, Zprávy České archeologické společnosti - Supplément 75. Praha, 23-25.

Chvojka, O. - Zavřel, P. 2011: Sídliště ze starší doby bronzové v Býšově, k. ú. Knín, okr. České Budějovice, Archeologie ve středních Čechách 15/1, 233-253.

Chvojka, O. - Zavřel, P. 2019: Archeologické výzkumy v trase dálnice D3 na Českobudějovicku - shrnutí výsledků za roky 2013-2018. In: Archeologické výzkumy v Čechách 2018. Sborník referátů z informačního kolokvia. Zprávy České archeologické společnosti - Supplément 113. Praha, 7-8.

Chvojka, O. - Zavřel, P. v tisku: Alt bekannt, neu untersucht. Ergebnisse der modernen archäologischen Forschung von drei vorgeschichtlichen Grabhügeln bei Plav, Kr. České Budějovice, Fines Transire 29, v tisku.

Jankovská, V. 2001: Paleobotanická rekonstrukce př́írodního prostředí kultury únětické a středověku na lokalitě České Budějovice - Dobrovodská stoka. In: Hašek, V. - Nekuda, R. - Unger, J. (eds.), Ve službách archeologie 3. Brno, 92-98.

Kuna, M. a kol. 2004: Nedestruktivní archeologie. Teorie, metody a cíle. Praha.

Kuna, M. - Slabina, M. 1987: Zur Problematik der Siedlungsareale (in der Bronzezeit). In: Archaeologische Rettungstaetigkeit in den Braunkohlengebieten und die Problematik der siedlungs-geschichtlichen Forschung. Prag, 263-278.

Limburský, P. a kol. 2018: Pohřební areály únětické kultury ve Vliněvsi. Praha.

Michálek, J. 2013: Výzkum sídliště ze starší doby bronzové v nivě řeky Blanice u Čavyně 2010-2012. In: Vodňany a Vodňansko 9. Vodňany, 7-30.

Militký, J. - Zavřel, P. 1995: České Budějovice, Výzkumy v Čechách 1990-1992, 56.

Moucha, V. 2005: Hortfunde der frühen Bronzezeit in Böhmen. Praha.

Neustupný, E. 2010: Teorie archeologie. Plzeň.

Parma, D. 2015: Poznámky k interpretačnímu potenciálu běžných sídelních areálů doby bronzové. In: Jan Bouzek and the Czech Lands. Studia Hercynia XIX/1-2, 96-110.

Pokorný, P. a kol. 2002: Pokorný, P. - Kočár, P. - Jankovská, V. - Militký, J. - Zavřel, P., Archaeobotany of the High Medieval town of České Budějovice (Czech Republic), Archeologické rozhledy 54, 813-836. 
Schefzik, M. 2001: Die bronze- und eisenzeitliche Besiedlungsgeschichte der Münchner Ebene. Eine Untersuchung zu Gebäude- und Siedlungsformen im süddeutschen Raum, Internationale Archäologie 68. Rahden/Westf.

Schefzik, M. 2006: Frühbronzezeitliche Gebäudeformen in Süddeutschland. Mit einer Gegenüberstellung des Formenbestandes der östlich angrenzenden Kulturlandschaften. In: Blajer, W. (ed.), Z badań nad osadnictwem epoki brazu i wczesnej epoki zelaza w Europie Środkowej. Kraków, 139-158.

Torbrügge, W. 1959: Die Bronzezeit in der Oberpfalz. Materialhefte zur bayerischen Vorgeschichte 13. Kallmünz/Opf.

Vencl, S. a kol. 2006: Nejstarší osídlení jižních Čech. Paleolit a mesolit. Praha.
Vencl, S. - Fridrich, J. 2007: Archeologie pravěkých Čech 2. Paleolit a mezolit. Praha.

Vondrovský, V. - Chrojka, O. (eds.) 2021: Kontinuita pravěkých komunit vnitřní periferie? Vývoj osídlení jižních Čech od 9. do počátku 1. tisíciletí př. Kr. České Budějovice, v tisku.

Zavřel, P. 1993: Současný stav znalostí o pravěku území města České Budějovice, Jihočeský sborník historický 62, 3-29.

Zavřel, P. 1998: Litvínovice, okr. České Budějovice, Výzkumy v Čechách 1996-1997, 106.

Zavřel, P. 2000: Vrábče, Výzkumy v Čechách 1998, 225.

Zavřel, P. 2003: Hůry, Výzkumy v Čechách 2001, 82. 


\section{Flachlandsiedlungen der frühen und beginnenden mittleren Bronzezeit im Gebiet von České Budějovice.}

Die wichtigsten Wissensquellen der frühen und beginnenden mittleren Bronzezeit (Bz A2 - B1) in Südböhmen stellten lange Zeit Höhenfundstellen, Gräberfelder und Hortfunde dar (vgl. z. B. Hájek 1954; Havlice 2001; Moucha 2005; Chvojka 2007; Hlásek et al. 2015). Erst in den letzten Jahrzehnten wuchs die Anzahl der bekannten und professionell erforschten Flachlandsiedlungen in der Region (Hlásek - Chvojka 2019, Abb. 2). Viele von ihnen wurden in den letzten 30 Jahren im Kreis České Budějovice untersucht, d.h. in einer der Knotenmikroregionen Südböhmens, in denen sich die Siedlungen dieser Epoche erheblich konzentrierten $(A b b .1)$. In diesem analysierten Gebiet sind heute insgesamt 16 sichere Flachlandsiedlungen der Stufen Bz A bis Bz B1 bekannt (Abb. 2). Daneben sind dort mehrere Dutzend weitere potenzielle Siedlungen bekannt, die nach heutigem Kenntnisstand jedoch noch nicht mit Sicherheit auf diese Weise klassifiziert werden können.

Der Stand der Untersuchung der Flachlandsiedlungen ist unterschiedlich, was es derzeit unmöglich macht, ihre inneren Strukturen zu vergleichen und eine genauere Chronologie der einzelnen Fundstellen zu bestimmen. Nach heutigem Kenntnisstand scheint die Siedlung bei Hosty, die sich in vielerlei Hinsicht von anderen zeitgenössischen Flachlandsiedlungen unterscheidet, völlig außergewöhnlich zu sein (Beneš 1988; 1989; Břicháček 1991). Diese Fundstelle ist die einzige im analysierten Gebiet, die eine spezialisierte Produktion aufweist, insbesondere nachgewiesene metallurgische Aktivität (Tiegel, ein Gußformfragment, ein Ringbarrenbruchstück, Gußstücken). Häufiger brachten die untersuchten Fundstellen Belege des Fernhandels, wie z.B. Bernsteinfunde (Hosty, Borek, Plav?). Die Fernkontakte weisen auch auf einige Keramikformen sowie Keramikverzierungen hin, wiederum hauptsächlich von der Siedlung in Hosty, vereinzelt aber auch von anderen Fundstellen (z. B. Borek, České Budějovice).

Aus topografischer Sicht ist die Verbindung dieser Siedlungen mit der Fluss Moldau besonders auffällig $(A b b .2)$, die zu dieser Zeit einen wichtigen Fernhan- delskorridor darstellte. Ein großer Teil der Fundstellen befindet sich in den heutigen Auen (Tabelle 1) und mehr als zwei Drittel von denen liegen auf einem sandigen Untergrund (Tabelle 2). Es ist die Lage der meisten Siedlungen auf sandigen Sedimenten, der in diesem Gebiet spezifisch ist und eine weitere Aufmerksamkeit erfordert.

Für ein besseres Verständnis der inneren Strukturen und der Objekte der analysierten Flachlandsiedlungen ist das größte Handicap der geringe Kenntnisstand der überwiegenden Mehrheit der Fundstellen. Nur die Siedlung von Hosty wurde systematisch freigelegt (Beněs 1988; Břicháček 1991). Auf einer Fläche von mehr als $100 \mathrm{~m}^{2}$ wurden Flachlandsiedlungen in Borek, České Budějovice (Nr. 3), Knín, Plav, Staré Hodějovice und Vrábče zumindest teilweise entdeckt, die anderen wurden nur in kleinen Flächen oder in Schnitten erfasst. In Bezug auf die Größe der analysierten Fundstellen scheinen zwei Gruppen unterscheidbar zu sein - die erste umfasst Siedlungen mit einer Größe von etwa 1 bis 3 ha (z. B. Hosty, Staré Hodějovice), die zweite Gruppe besteht aus Fundstellen mit einer maximalen Größe von 0,1 bis 0,5 ha (z. B. Knín - Býšov, Vrábče).

Von den untersuchten Fundstellen lieferte die meisten Informationen über die innere Struktur die Siedlung in Hosty, wo eine Reihe von Pfostenstrukturen, die über das gesamte Forschungsgebiet verstreut waren, sowie zwei nicht gleichzeitige Gräben mit einer Breite von $2 \mathrm{~m}$ und $4 \mathrm{~m}$ nachgewiesen werden konnten (Abb. 3:A; Břicháček 1991, Abb. 2). Diese Fundstelle brachte mindestens 12 Häuser der Pfostenkonstruktionen $(A b b .3: B)$, in deren Nähe sich Lagergruben befanden (Bricháček 1991, 90). Eine andere Siedlung mit einem festgestellten potentiellen Wohngebäude ist die Fundstelle in Knín - Býšov (Abb. 4).

In vielen Flachlandsiedlungen wurden mehrere übliche Siedlungsgruben dokumentiert, für die es normalerweise unmöglich ist, ihre ursprüngliche Funktion zu bestimmen, obwohl einige Hinweise auf Produktionsaktivitäten in der Wohnsiedlung liefern 
können (Abb. 5-6). In einigen Fundstellen wurden auch Kulturschichte erfasst (z. B. Hosty, Knín Býšov, Plav: $A b b .7$ ), aus denen die meisten Artefakte stammen. Andere südböhmische Siedlungen, die sich in heutigen Überschwemmungsgebieten befinden, brachten Belege der erodierten und akkumulierten Kulturschichten (Abb. 8).

Die meisten der analysierten Siedlungen können nicht genauer chronologisch klassifiziert werden, da weniger signifikante Siedlungsfunde normalerweise keine feinere Chronologie zulassen. Von den 16 Flachlandsiedlungen im Gebiet von České Budějovice können derzeit nur vier chronologisch genauer klassifiziert werden. Die einzige Siedlung (in České Budějovice) kann mit einiger Vorsicht in die älteste Phase der südböhmischen Frühbronzezeit, d.h. in die Stufen Bz A1/A2, eingeordnet werden. Mehrere Besiedlungsbelege in Südböhmen fallen in die $\mathrm{Bz}$ A2-Phase, von den Flachlandsiedlungen kann jedoch nur eine mit Sicherheit aufgenommen werden - die ältere Phase der Besiedlung in Hosty (Beneš 1988,
11; Břicháček 1991, 90, 93). Diese Fundstelle wurde (ununterbrochen?) auch in die folgende Phase $\mathrm{Bz}$ A2/B1 besiedelt, gleich wie die kürzlich untersuchte Siedlung von Borek. Neben einer größeren Menge typischer Keramik (Abb. 9) wird die Datierung dieser Siedlung auch durch das Radiokarbondatum 3430 BP \pm 25 (nach Kalibrierung 1876-1630 v. Chr.; Chvojka - Šálková - Š́da a kol. 2021) gestützt. Vielleicht gehört in diese Phase auch die Siedlung in České Budějovice - „Dobrovodská stoka“, wie aus zwei Radiokarbondaten $1714 \pm 136$ v. Chr. und 1634 \pm 135 v. Chr. (Jankovská 2001) hervorgeht. Bisher kann keine Flachlandsiedlung in der Region České Budějovice sicher in die frühe Phase der Mittelbronzezeit Bz B1 einbezogen werden.

Die meisten analysierten Flachlandsiedlungen weisen keine direkte Verbindung zu anderen zeitgenössischen Fundstellen auf. Alle Siedlungen befinden sich jedoch in einer relativ dicht besiedelten Landschaft mit Belegen von mehreren Gräberfeldern, Burgwällen sowie Hortfunden. 


\section{Doc. Mgr. Ondřej Chvojka, Ph.D.}

\section{- Archeologický ústav,}

Filozofická fakulta, Jihočeská univerzita,

Branišovská 31a, 37005 České Budějovice, CZ

ochvojka@ff.jcu.cz

\section{- Jihočeské muzeum}

Dukelská 1, 37051 České Budějovice, CZ

chvojka@muzeumcb.cz 